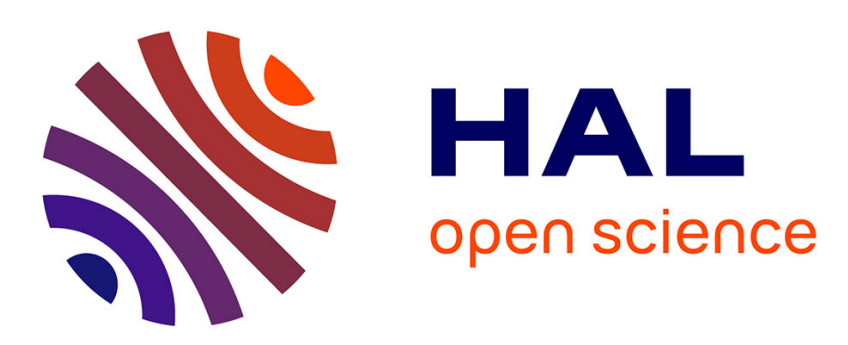

\title{
The comparison of topographic long profiles of gullies on Earth to gullies on Mars: a signal of water on Mars.
}

Susan Conway, Matthew Balme, Mikhail A Kreslavsky, John Murray, Martin C Towner

\section{- To cite this version:}

Susan Conway, Matthew Balme, Mikhail A Kreslavsky, John Murray, Martin C Towner. The comparison of topographic long profiles of gullies on Earth to gullies on Mars: a signal of water on Mars.. Icarus, 2015, 253, pp.189-204. 10.1016/j.icarus.2015.03.009 . hal-02272843

\section{HAL Id: hal-02272843 \\ https://hal.science/hal-02272843}

Submitted on 28 Aug 2019

HAL is a multi-disciplinary open access archive for the deposit and dissemination of scientific research documents, whether they are published or not. The documents may come from teaching and research institutions in France or abroad, or from public or private research centers.
L'archive ouverte pluridisciplinaire HAL, est destinée au dépôt et à la diffusion de documents scientifiques de niveau recherche, publiés ou non, émanant des établissements d'enseignement et de recherche français ou étrangers, des laboratoires publics ou privés. 
1 The comparison of topographic long profiles of gullies on Earth to gullies on Mars: a signal of 2 water on Mars.

3 Susan J. Conway ${ }^{1 *}$

4 Matthew R. Balme ${ }^{1,2}$

$5 \quad$ Mikhail A. Kreslavsky ${ }^{3}$

6 John B. Murray ${ }^{4}$

7 Martin C. Towner ${ }^{5}$

$8 \quad{ }^{1}$ Department of Physical Sciences, Open University, Milton Keynes MK7 6AA UK

9 (susan.conway@open.ac.uk)

10 2Planetary Science Institute, 1700 E. Fort Lowell, Suite 106, Tucson, AZ 85719-2395, USA

$11{ }^{3}$ Earth and Planetary Sciences, University of California, Santa Cruz, CA 95064, USA

$12{ }^{4}$ Earth, Environment and Ecosystems, Open University, Milton Keynes MK7 6AA UK

$13{ }^{5}$ Dept of Applied Geology, Curtin University, Perth, GPO Box U1987, WA 6845 Australia.

$14 *$ Corresponding author 
The topographic signature of a landform can give important clues as to its formation process. Here, we have used topographic long profiles to study the process of gully formation on Mars. We studied topographic long profiles of gullies on Earth to (1) confirm that previously published generalisations of how long profile shape varies with process also applies at the kilometre-scale of martian gullies, and (2) use as a direct comparison with the martian data. We have compared 24 fluvial and 22 debris flow long profiles of terrestrial gullies derived from laser altimeter and GPS measurements, to 78 long profiles of a range of gullies on Mars derived from a stereo-photogrammetry point-matching technique. We have confirmed that this manual point-matching technique is reliable for the martian data by comparison with full digital elevation models. We used nine different characteristics of the long profiles, including slope and curvature parameters, to perform a canonical discriminant analysis, which allowed us to identify the variables most important for differentiating between fluvial and debris flow gullies on Earth. In agreement with published literature for larger-scale features, we found that terrestrial debris flow gullies tend to be steeper and less concave than fluvial gullies. We have found that gully long profiles on Mars can resemble long profiles of terrestrial gullies formed by either fluvial or debris flow processes, with slightly more affinity to fluvial systems. Gullies on Mars can only be weakly separated from those on Earth: they can be separated from terrestrial fluvial gullies on curvature parameters and from terrestrial debris flow gullies by slope parameters. In addition, we have found that different alcove types identified from planview morphology are also distinctive in terms of their long profile morphology: gullies which incise back into the bedrock are more similar to terrestrial debris flows whereas polar-pit gullies are most similar to terrestrial fluvial gullies. Our findings suggest that the presence of a bedrock alcove promotes debris flow behaviour in gullies on Mars. 


\section{Introduction}

41

42

\subsection{Martian gullies}

Gullies on Mars are so named because they visually resemble gullies found on Earth carved by fluvial processes. The most recent martian gullies are estimated to have formed in the last few million years (Reiss et al., 2004; Schon et al., 2009) and are found on steep slopes, including impact crater walls, mesa escarpments, and valley walls, amongst others (Balme et al., 2006; Dickson et al., 2007). Their mode of formation is controversial, because they resemble features on Earth formed by water, but the climate of Mars during the Amazonian (the last $\sim 2 \mathrm{Ga}$ ) is not believed to be conducive to the production of liquid water at the martian surface. Since their discovery by Malin and Edgett (2000), a range of different hypotheses have been proposed for their formation, including: dry mass wasting (e.g., Treiman, 2003), $\mathrm{CO}_{2}$ gas supported flow (e.g., Cedillo-Flores et al., 2011), frosted granular flow (Hugenholtz, 2008), top-down seasonal melting of ground ice/snow with day-average temperatures $>0^{\circ} \mathrm{C}$ (Christensen, 2003; Costard et al., 2002), top-down diurnal melting of snow/frost producing metastable water when day-average temperatures are $<0^{\circ} \mathrm{C}$ (Hecht, 2002) and aquifer outflow (Heldmann et al., 2005; Malin and Edgett 2000). Global studies have revealed that gullies are concentrated in the mid-latitudes, and are not found equatorwards of $30^{\circ} \mathrm{N} / \mathrm{S}$. They predominantly face polewards in the mid-latitudes but have less orientation preference elsewhere (Balme et al., 2006; Dickson et al., 2007; Harrison et al., 2014; Heldmann et al., 2005; Kneissl et al., 2010). This, together with the observations that other ice-related landforms such as viscous flow features, concentric crater fill and degraded mantle, are also found predominantly in the mid-latitudes (Dickson et al., 2012; J. Levy et al., 2010; Milliken et al., 2003; Souness et al., 2012) has built a community consensus that gullies are intimately linked to the shifting and re-equilibration of surface-ice deposits (water and/or $\mathrm{CO}_{2}$ ) under the influence of recent changes in climate driven by Mars' large obliquity variations (Head et al., 2003). Detailed morphological observations also favour the implication of liquid water in gully formation, including: sinuosity on high slope angles (Mangold 
et al., 2010), cut-bank terraces (Schon and Head, 2009), streamlined islands, occasional levees (Johnsson et al., 2014; Lanza et al., 2010; J. S. Levy et al., 2010) and braided channels (Gallagher et al., 2011).

In this work we take the comparison with gullies on Earth further, by measuring the topographic long profiles of gullies on Earth formed by different processes, which we then compare to gullies on Mars.

\subsection{Topographic long profiles as indicators of process}

In the study of river geomorphology, long profiles are used to show the change in elevation and slope of the channel with downstream distance (e.g., Hack, 1957). River channel and slope long profiles preserve signatures of tectonics, climate, lithology and structure. Each of these factors modulates the dominant processes acting on the profile and leaves a morphological heritage. Slope profiles have been used to characterise the landscape change brought about by different processes, such as rockfall, solifluction, debris flows (sediment-rich water flows) and overland water flow. Certain long-profile properties are considered characteristic of a particular process and those relevant to martian gullies include debris flow and fluvial, or clear-water, flows. Unconfined hillslope debris flows tend to form a profile with a steep linear upper section and a concave lower section (Ballantyne and Benn, 1994; Church et al., 1979; Larsson, 1982). Water-worn gullies on Earth and more developed fluvial systems show a range of morphologies. However, the equilibrium state is considered to be a curve of exponential decay (e.g., Hack, 1957). This has been recently generalised to a power law relation of elevation to downstream distance (Goldrick and Bishop, 2007).

It has been noted that in mature fluvial systems parts of the channel long profile with a gradient greater than $\sim 0.03-0.1$ are often dominated by debris flow processes (Stock and Dietrich, 2006). Several studies have found that the influence of debris flow deposition on a fluvial system decreases 
the concavity of the river channel profile (Brardinoni and Hassan, 2006; Mao et al., 2009) and can sometimes cause it to become convex (Hanks and Webb, 2006).

Little work has been done on discriminating process based on slope profile measurements in small, relatively young catchments on Earth, which have a similar spatial length-scale $(1-2 \mathrm{~km})$ to martian gullies. These systems have the benefit that they usually have a spatially uniform lithology, structure, climatic history and tectonic history and thus have a quantifiable morphological heritage. In order to capture the natural variation in long profile parameters introduced by different geologic and climatic settings, we chose terrestrial gullies from different parts of the world, with different climate, lithology and tectonics. Considering this inevitable natural variability we did not anticipate being able to find a single parameter that would be indicative of a single process. Therefore in this paper we present a statistical analysis, which uses a range of long profile properties and produces a set of differently weighted parameters, which together can be used to indicate process. Similarly on Mars we have selected gullies in a wide range of settings and latitudes, which we anticipate also span a range of different lithologies, climatic settings and geologic histories (as on Earth). Therefore using our statistical approach we aim to understand whether the natural range of possible martian gully long profile shapes is consistent with those found on Earth and further whether particular visible attributes correlate with debris flow or fluvial gully long profiles on Earth.

First we present data from ephemeral water-worn gullies and debris flow gullies on Earth that, at the length-scale relevant to martian gullies, confirm the differences in long profile predicted by the literature. We have then compared the results to gullies on Mars, to determine the process of gully formation there, in doing so we have taken into account the difference in gravitational acceleration between the two bodies. In addition, we compared the profile-properties of gullies with different plan view morphological alcove types. The aims of these analyses were to (1) determine if long profiles of gullies on Mars preserve the signature of debris flow, or pure water flow (or both, or 

processes.

\section{2. Study Sites}

\subsection{Sites Studied on Earth}

Five terrestrial analogue sites were studied. Two of these had debris flow as the dominant gully forming process: Colorado Front Range in the USA and the Westfjords of NW Iceland. Three had ephemeral water flow as the dominant gully formation process: Death Valley, California; San Jacinto, California and La Gomera in the Canary Islands, Spain. We describe each of these sites in more detail below and a summary of their attributes, including their latitudes and longitudes, is given in Table 1.

\subsubsection{Fluvial end-members}

\section{San Jacinto, California}

This site is located in California along a splay of the San Andreas Fault, called the San Jacinto fault. The study area is a desert, experiencing little rainfall, and has undergone rapid recent uplift caused by the fault system. The landscape has a well-developed ephemeral gully network with large alluvial fans formed by fluvial processes. The vegetation is sparse, consisting of small scrub bushes. The underlying geology of the study area is mainly granite, schist and gneiss with minor outcrops of Quaternary "older fan deposits" (Moyle, 1982). The gullies incise into bedrock in the alcove portion, and then progress over previous fan deposits (Fig. 1a). The elevation data used in this study are derived from airborne laser altimetry data (or LiDAR) with an average point spacing of $2.98 \mathrm{pts} / \mathrm{m}^{2}$ flown by the National Center for Airborne Laser Mapping (NCALM) as part of the "B4" project (http://dx.doi.org/10.5069/G97P8W9T) between $18^{\text {th }}$ and $27^{\text {th }}$ May 2005. The data were downloaded as a gridded data product at $1 \mathrm{~m} / \mathrm{pix}$ from Open Topography (http://www.opentopography.org). 
This site is located a few kilometres NE of Ubehebe crater in Death Valley, California. This is a desert

137 area that has well developed ephemeral gully networks with large alluvial fans. There is little 138 precipitation, although the nearby mountains receive as much as $85 \mathrm{~mm}$ of rain per year (Crippen, 139 1979). Debris flows are found on the fans in the area, but the primary process active in the gullies is fluvial deposition (Crippen, 1979). The bedrock consists of Palaeozoic sedimentary rocks (Workman et al., 2002). Similarly to the San Jacinto site, the gullies incise into bedrock in the alcove portion, and then progress over previous fan deposits (Fig. 1b). The elevation data used in this study are derived from airborne LiDAR with an average point spacing of $2.03 \mathrm{pts} / \mathrm{m}^{2}$ flown by the NCALM (http://dx.doi.org/10.5069/G9T151KN) on $28^{\text {th }}$ February 2005. The data were downloaded as a gridded data product at $1 \mathrm{~m} /$ pix from Open Topography (http://www.opentopography.org).

\section{La Gomera}

Profiles of gullies were measured in south-western La Gomera, where the climate is semi-arid to fully arid. Gullies here have been compared to martian gullies in previous work (Marquez et al., 2005). The island is volcanic in origin and volcanic activity ceased about $4 \mathrm{Ma}$ ago (Ancochea et al., 2006) since which time the island has been subject to intense fluvial erosion (Llanes et al., 2009). The geology underlying the gullies studied is classified as Old Edifice (10-6.2 Ma) with a mixture of mostly horizontal bedded lavas, pyroclastic and breccia deposits. We collected the elevation data for the three short profiles with differential GPS in the field in May 2008 (using the same methods as described in Conway et al., 2010). Additional data for these profiles (in areas too steep to reach by foot) and additional longer profiles were taken from a $10 \mathrm{~m}$ digital elevation model (DEM) from GRAFCAN (Canary Island Mapping Agency). In contrast to all the other sites, none of the gullies in La Gomera had developed depositional fans, and their terminations were either at the sea or the valley bottom. The gullies incised into bedrock in their alcove areas. In their lower portions they incise into 
(Fig. 1c). The profiles in La Gomera in which data from the $10 \mathrm{~m}$ DEM were used had some irregularities in the lower parts as a result of the low resolution of the DEM (at worst random fluctuations of $\sim 20 \mathrm{~m}$ vertically for profiles with $850 \mathrm{~m}$ drop and $1.5 \mathrm{~km}$ length, but usually fluctuations of $<5 \mathrm{~m}$ ).

\subsubsection{Debris flow end members}

\section{Front Range, Colorado}

This site is located in the mountainous eastern side of the US continental divide. The area was deglaciated around 14,000 to 12,000 years before present (Godt and Coe, 2007) and the landscape is dominated by glacially carved valleys. This area has many active debris flows (Coe et al., 2002; Godt and Coe, 2007) and has no permanent snowpack. The study slopes, located above the tree line, are dominated by Precambrian biotitic gneiss and quartz monzonite, scattered Tertiary intrusions, and various surface deposits, all of which host debris flows (Godt and Coe, 2007). The head and sidewalls of the cirques have large rockfall talus deposits, which also contain active debris flows. These slopes have little or no vegetation. The gully-alcoves are incised into the bedrock, but for the majority of their length they incise into and rework previous debris flow deposits and other slope deposits (Fig. 1d). The terminal parts of these gullies sometimes coalesce to form a continuous apron and sometimes form a discrete fan (Fig. S1). The elevation data used in this study are derived from airborne LiDAR with an average point spacing of $1.83 \mathrm{pts} / \mathrm{m}^{2}$ flown by the NCALM (http://dx.doi.org/10.5069/G9N877QJ) on $29^{\text {th }}$ September 2005. The data were downloaded as a gridded data product at $1 \mathrm{~m} /$ pix from Open Topography (http://www.opentopography.org).

\section{Westfjords, Iceland}

The site is located in NW Iceland, and is dominated by fjords and glacially carved valleys. The last glacial retreat occurred approximately 10,000 years before present (Norđdalh, 1990). The valley walls have many active debris flows (Conway et al., 2010) and on the slopes above Ísafjörður (Fig. 

high levels of both snow and rainfall, but does not have permanent ice or snow patches. The site is underlain by Miocene basalts, although the debris flows occur generally in glacial till. The gullyalcoves are incised into the bedrock, but for the majority of their length they incise into and rework previous debris flow deposits and other slope deposits. The terminal parts of these gullies often coalesce to form a continuous apron, rather than a discrete fan (Fig. 1e). The DEM at $1 \mathrm{~m} / \mathrm{pix}$ for NW Iceland was produced from raw LiDAR point data collected by the UK Natural Environment Research Council's Airborne Research and Survey Facility in 2007 using techniques described by Conway et al. (2010).

\subsection{Sites Studied on Mars}

We extended the catalogue of Mars Orbiter Camera narrow angle (MOC-NA) images containing gullies compiled by Balme et al. (2006) up to orbit R10 and also added High Resolution Science Imaging Experiment (HiRISE) images up to the March 2009 Planetary Data System (PDS) release. We added more images to the HiRISE catalogue by finding all images which overlapped with the image footprints included in the MOC-NA catalogue. HiRISE image pairs suitable for extraction of stereo elevation data were identified using the "Find Overlapping Polygons" script for ArcMap by Ken Buja (http://arcscripts.esri.com/details.asp?dbid=15198) which also allowed extraction of the overlapping area of the image pairs.

From these image pairs we sampled gullies that had stereo HiRISE data coverage with greater than 50\% image overlap; these have wide geographic locations and settings (Fig. 2, Table 2). This procedure produced a greater number of potential pairs than just considering the images that are flagged as stereo-acquisitions by the HiRISE team. Hence, it includes images that are not necessarily suitable for automated stereo matching due to, for example, differences in albedo or illumination, but which are suitable for manual stereo matching. These data were then manually filtered based on 
artefacts or were of insufficient quality to identify matching points. Other image-pairs were rejected because they did not overlap in the correct location to cover whole gullies. The data were inspected in order of decreasing overlap. Table 2 lists the image pairs that passed these filtering procedures and have been used for our analyses.

$213 \quad 3 . \quad$ Approach

\section{$214 \quad$ 3.1. Extracting topographic profiles on Mars}

We adapted a manual point matching method developed by Kreslavsky (2008) for capturing point elevation data from Reduced Data Records (RDR) HiRISE images. Details of the Kreslavsky (2008) method are given in Appendix A. In brief, the $y$-parallax is calculated at user-defined points using the geometrically corrected JPEG2000 images released by the HiRISE team as a starting point. This method was used successfully by Parsons and Nimmo (2010) to study gully slopes. A summary of the procedure that we have followed is given below.

Using ESRI's ArcGIS we created point shapefiles for each image within a stereo pair. Matching points, such as boulders, were identified and digitised in both images. The estimated error for this matching is 1-3 pixels. Points along the line of the gully profile were digitised at 50-100 m spacing (Fig. 3), but this spacing varied according to the availability of features to match. Each point was classified as one or more of the following: "alcove", "channel", or "debris apron" (Fig. 3). The classifications were allocated as follows:

(1) alcove - any area where a flow would be confined (by bedrock or by a deep incision, or chute), lacked depositional features, detailed below, showed evidence of erosion, including terraces and/or steep incisions and was contributory in nature (different branches coming together downslope); 
(2) channel - any area where a distinct channel with discernible banks incised into non-bedrock material with lateral capacity for channel migration (the channel could be single or multiple thread and be contributory or tributary) ; and

234 (3) debris apron - any area where there was evidence of deposition, as indicated by the 235 presence of a fan-deposit(s), lateral lobate deposits, splay deposits, or levees.

Digitisation of the profile was started at the top of the slope and continued to the base of the debris apron. Each gully was given a unique identification number. For each point the $\mathrm{x}$ and $\mathrm{y}$ image pixel coordinates were extracted. The pixel coordinates were given from the top-left corner of the image and positive in the top-to-bottom and left-to-right directions. These coordinates were passed through the script developed by Kreslavsky (2008) and the output, consisting of the $x, y, z$ coordinates and an error term in metres were appended directly to the shapefiles. The coordinates are given relative to the centroid of the point array, rather than to Mars datum. The error term not only contains the error associated with the errors in digitisation, but also the error brought about by the assumptions made about the image geometry; further details can be found in Appendix A. A discussion of what this error represents in terms of a "real" vertical offset in metres is discussed in Section 4.

\subsection{Extracting long profiles on Earth}

The same system of digitisation and classification, as outlined in Section 3.1, was applied to long profiles on Earth. However, there was no need to run the points though the script developed by Kreslavsky (2008), because all the sites on Earth had underlying elevation data, which could be

251 directly assigned to the points.

\section{$252 \quad$ 3.3. Analysis of the Long Profiles}

253 All the long profiles were analysed to collect the following information: total planform length, total elevation difference, start-to-end gradient (slope of $A B$, Fig. 4), the range of slopes in the gully 
profile, concavity (three methods, detailed below) and the relative position of the maximal concavity. The length and the maximum, minimum and mean slopes were calculated for each individual portion of the gully (alcove, channel, debris apron). Slopes were calculated from the difference in elevation and horizontal separation between adjacent points. Concavity was derived using three methods:

(1) Following Demoulin (1998) we calculated the area between the straight line connecting the source to the distal extent of the deposits and the profile ( $\mathrm{Pa}$, Fig. 4$)$ expressed as a percentage of the triangle's area (AOB, Fig. 4). Pa only includes portions of the profile that drop below the straight line. This parameter is a proxy for the area eroded, $A_{\text {ero }}$. In addition we calculated the position of the maximal concavity (Eq, Fig. 4), which is the distance to the point in the profile where the vertical difference between the profile and the straight line is the greatest $\left(H_{\max }\right)$, normalised by the distance $O B$. This is otherwise known as the "Kennedy Parameter" (Allison and Higgitt, 1998). The smaller the value of $E q$, the better graded the profile. Conversely the larger the value of $A_{\text {ero, }}$ the better graded the profile (i.e. the more similar the profile to an "ideal" river profile following a curve of exponential decay).

(2) The relative concavity index (CI) of Phillips and Lutz (2008) was also calculated, in which the sum of the distances between the profile and the straight line $\left(H_{i}\right.$, Fig. 4$)$ is divided by the number of segments and normalised by the overall height drop ( $A O$, Fig. 4). $C l$ ranges between 1 and -1 , with negative values indicating convexity, positive values indicating concavity, and where a linear profile has the value of 0 .

We calculated the "DS index", or concavity index (७) of Goldrick and Bishop (2007), which is the gradient of the linear best-fit line in the plot of logarithmic slope against logarithmic distance. Negative values mean that the profiles are concave and positive that the profiles are convex.

\subsection{Additional information for long profiles on Mars}


Additional attributes were recorded at the sites of long profile collection on Mars, including setting and alcove type. Gully settings were defined as one of the following: inner crater rim, outer crater rim, crater central peak, crater central pit, valley wall, hill, dune or south polar pit. Alcove types were divided into four classes, adapted from Aston et al. (2011):

a) open - those alcoves which widen upslope and do not have a definite upper boundary.

b) cuspate - alcoves that have an arcuate upper termination within the host hillslope, i.e. do not extend up to the crest of the ridge.

c) bouldery - unique to the south polar pits, these alcoves are lined with numerous boulders and extend up to the top of the pit's inner slope.

d) rockwall- these alcoves form amphitheatre-shaped depressions in the bedrock of the host slope and extend up to and into the top of the slope.

We differentiated between these types using the following decision tree: firstly following the gully upwards from the fan if there was no topographic break at the top or the sides of the gully before the channel(s) became impossible to differentiate from the crater wall, these were "open", secondly if there was a topographic break delineating the alcove and the limits of the alcove did not extend to the top of the host hillslope, these were "cuspate", and thirdly if the limits of the alcove were well-defined by a topographic break and extended to the top of the hillslope and there was bedrock exposed in the alcove walls these were "rockwall", if instead the alcove was cut into material that seemed to be composed of boulders, these were "bouldery". These different alcove types are illustrated in Fig. 5.

\section{Validation of the point-matching method}

We tested the Kreslavsky (2008) method against published DEMs in order to (1) verify that the assumptions made in the method are not detrimental to the analysis of long profiles and, (2) to 
determine a value of error output value beyond which data should not be used for further analysis. We compared the results from profiles analysed by the Kreslavsky (2008) method to profiles taken from four HiRISE DEMs (Table 3). The derivation of the HiRISE DEMs and associated errors are described in Conway, et al. (2011). The vertical precision of these DEMs is estimated to be $\sim 0.24 \mathrm{~m}$. Hence the error in elevation is very small and, for the purposes of this work, to be considered as "truth" in terms of comparison with the results from the point matching method. The position of the points in the DEM profile was matched to be as close as possible to the position of the points in the manual profiles. We estimate that approximately $1 \mathrm{~m}$ of positioning mismatch could have been introduced by transferring the profile-points to the DEM profile.

The difference between the profile parameters (detailed in Section 3.3) calculated using the elevations from the DEMs and those calculated from elevations derived using the Kreslavsky (2008) method are shown in Table 4. Two of the profiles (Site F, Gully ID 1 and Site G, Gully ID 1) have high values of stereo error and correspondingly also have relatively large differences between the DEM profile and manual profile parameters (although rarely greater than $10 \%$ ).

Reassuringly, the profiles with values of stereo error $<10 \mathrm{~m}$ also have small differences between their profile parameters calculated with the two different elevation data-sources. This is a good first indication that the stereo error output of the Kreslavsky (2008) method is a reasonable estimate of the real error. These profiles have at worst $2^{\circ}$ differences in slope, $7 \%$ difference in length, and $3.5 \%$ difference in elevation. For the concavity measures, $\mathrm{Cl}$ has possible values between -1 and 1 , so our values are within $0.5 \%$ of the DEM-calculated values; Eq can range between 0 and 1 , so our values differ by $\ll<1 \% ; \vartheta$ has values as low as -1 in Goldrick and Bishop (2007), so our values differ by $<1 \%$; and $A_{\text {ero }}$ can have values of up to 0.5 (Demoulin, 1998), so our values differ by up to $5 \%$ which is still reasonable.

Using this comparison we were able to assess how the stereo error generated by the Kreslavsky (2008) method compared to the real deviation from the HiRISE DEMs. This was done by taking every 
consecutive pair of points in the profile and combining their stereo error using the standard formula $\sigma Z=\mathrm{V}\left(\sigma A^{2}+\sigma B^{2}\right)$, where $\sigma Z$ is the total uncertainty, and $\sigma A$ and $\sigma B$ are the uncertainties of the two points. Then, the first point of the pair was considered as fixed and the difference in elevation between the DEM and the Kreslavsky (2008) method was calculated for the second point. The plot of the combined stereo error against this elevation difference is shown in Fig. 6 . Although there is no linear trend linking the stereo error with the elevation difference, it is clear that even if the stereo error is of the order of $\sim 15 \mathrm{~m}$, this value corresponds to an elevation difference of $5 \mathrm{~m}$ in the worst case, and more likely $<2 \mathrm{~m}$. This magnitude of elevation difference can lead to errors in slope calculations of the order of $\sim 1^{\circ}$, or $3^{\circ}$ at worst for our profiles.

Also reassuringly, very large stereo errors (> $100 \mathrm{~m}$ ) correspond to very large differences in relative elevation estimated between the DEM and the Kreslavsky (2008) method (Table 4). The mean stereo error was not as reliable an indicator of error as that for the whole profile. Stereo errors often fluctuated around zero, so a profile with average error of zero could have extreme positive and negative values, as demonstrated by site F Gully ID 1 in Table 4. The standard deviation was a better guideline and a cut off value of $20 \mathrm{~m}$ was chosen to provide a criterion to discriminate between profiles to include and profiles to exclude from further analysis. From visual inspection, a value of around $20 \mathrm{~m}$ for the standard deviation was often due to a single outlier.

\section{Canonical Discrimination analyses}

Canonical discrimination analysis (McLachlan, 2004) was performed on the profile parameters to: (1) enable the identification of the parameters that were important for separating fluvial and debris flow gullies on Earth, and (2) to determine if martian gullies have unique characteristics that could separate them from terrestrial gullies. Canonical discrimination analysis attempts to find a linear combination of variables that best separates any given groups. It uses a similar approach to principal components analysis, but instead of trying to best separate the data in general it tries to furthest separate the groups. The first function generated by the canonical discrimination analysis is the 
linear combination for which the separation between groups is maximised. The second function is a linear combination uncorrelated with the first function for which the separation between groups is maximised, and so on, until a number equal to $n$ - 1 functions is reached, where $n$ is the number of groups. Standardised versions of the variables (i.e. the variables are transformed so that their mean is 0 and their variance is 1 ) are used in this analysis to allow assessment of the relative importance of the variables within each discriminant function. The standardised canonical discriminant function coefficients with the largest magnitude for a given analysis are those that are most important in the separation of the input groups.

To allow for the different scales of the terrestrial fluvial gullies, terrestrial debris flow gullies and gullies on Mars, we only included parameters that are independent of the scale, namely slope range, average alcove slope, average channel slope, average debris apron slope, erosion area $\left(A_{\text {ero }}\right)$, relative concavity index $(C l)$, concavity index $(\vartheta)$, position of the maximal concavity $(E q)$ and gradient.

\section{Results}

We studied 24 profiles in terrestrial fluvial settings and 22 profiles in terrestrial debris flows settings, the positions of the individual profiles are given in Fig. S1. On Mars, we studied 78 gullies across 38 sites (Fig. 3, Table 2 and locations of the individual profiles in Fig. S2). Using the $20 \mathrm{~m}$ error value cutoff, 10 profiles and 6 image pairs were eliminated from the martian study sample (Table 2). The majority of gully profiles on Mars were associated with craters, 59 of which were on inner crater hills and one on a valley wall.

\subsubsection{Profile dimensions and concavity}


The selected terrestrial fluvial gullies have a wide range of lengths and height drops (Table 5), with lengths ranging from $150 \mathrm{~m}$ to $1.8 \mathrm{~km}$ (median $560 \mathrm{~m}$ ) and height drops 75 to $840 \mathrm{~m}$ (median $200 \mathrm{~m}$ ). Fluvial gullies have a median value of concavity $(\mathrm{Cl})$ of 0.22 . Compared to fluvial gullies, debris flow gullies (Colorado Front Range and Iceland) have a restricted range of lengths and height drops (Table 5): lengths range from $390 \mathrm{~m}$ to $1.3 \mathrm{~km}$ (median $780 \mathrm{~m}$ ) and height drops 250 to $680 \mathrm{~m}$ (median $430 \mathrm{~m}$ ). Their profile shape is only slightly concave $(\mathrm{Cl}$ median $=0.15)$ and, compared to fluvial gullies, have a lower range in values. Debris flow gullies are less concave no matter which type of concavity measurement is used. Unlike the fluvial gullies, many of the debris flow profiles have a basal concavity, as indicated by a value of $E q$ greater than 0.5 (median 0.58 ), i.e. they are more concave in the lower parts.

Martian gullies have an even wider range of lengths $(0.35-6.4 \mathrm{~km}$, median $1.3 \mathrm{~km})$, height drops (0.14-2.1 km, median $0.49 \mathrm{~km})$ and profile shape than either debris flow or fluvial gullies on Earth. Some martian profiles are convex in profile (hence negative $\mathrm{Cl}$ values). From these simple comparisons some qualitative differences between fluvial, debris flow and martian gullies seem to be apparent. However, to determine which properties of the profiles best separate different gullytypes, we use canonical discriminant analysis and the results of these analyses are given in the following sections.

\subsubsection{Canonical Discrimination analyses}

First we analysed which variables best separated terrestrial fluvial and debris flow gullies designated as canonical analysis " $\mathrm{A}$ " in the following text, tables and figures. Table 6 provides the function coefficients that best separate terrestrial fluvial gullies and terrestrial debris flow gullies (canonical coefficients A1), shown visually as a boxplot in Fig. 7. Figure 7 shows that the terrestrial fluvial and debris flow gullies are separable using these parameters - the bodies of the boxplots (quartiles) do not overlap, and there is only a slight overlap of the box-plot 'whiskers' (the maximum and minimum values). 
Table 6 enables us to assess the relative importance of the measured parameters comprising coefficient A1, giving us the following ranking, in descending order of importance: gradient, position of maximal concavity $(E q)$, average alcove slope, relative concavity index $(C l)$, eroded area $\left(A_{\text {ero }}\right)$, average debris apron slope, average channel slope, range in slopes and concavity index $(\vartheta)$. The parameter with the smallest magnitude, $\vartheta$, has $1 / 8$ the weight of the most important parameter and all the others have $1 / 3$ the weight of the most important parameter or greater, showing that all the parameters participate significantly in separating the two groups, (i.e. we cannot exclude any given parameter and achieve about the same separation).

Figure 7 also shows the $\mathrm{A} 1$ discriminant function applied to gullies on Mars. Although the martian data overlap both the data for fluvial and debris flow data for Earth, they overlap slightly more with fluvial gullies than debris flow gullies. Importantly, the range of values for the canonical function A1 applied to the martian gully profiles does not extend significantly beyond the range of values expressed by the terrestrial gullies, suggesting very similar profile-forms are found on Mars.

Secondly, we calculated the canonical discriminant functions that best separate terrestrial fluvial gullies, terrestrial debris flow gullies and gullies on Mars, aiming to assess whether there are specific parameters unique to gullies on Mars. This analysis is designated as canonical analysis " $\mathrm{B}$ " in the following text, tables and figures. The resulting coefficients B1 and B2 are given in Table 6, and Fig. 7 is a plot of the two canonical discriminant functions. Figure 7 shows that gullies on Mars can be separated from those on Earth, but that there is overlap between them and the terrestrial gullies. The vectors on Fig. 7 show that gradient and slope parameters separate martian gullies from terrestrial debris flow gullies (predominantly gradient and alcove slope) and concavity parameters (predominantly $\vartheta$ and $C l$ ) separate martian gullies from terrestrial fluvial gullies.

Figure 8 shows scatter plots of some of the important variables identified in the canonical analyses A and $\mathrm{B}$ (average alcove slope, average debris apron slope, $\mathrm{Cl}, \mathrm{Eq}$, overall gradient); the significant trends are summarised below. Fluvial gullies have higher $\mathrm{Cl}$ concavity values than debris flow gullies 
and martian gullies tend to have similar values to debris flows, but sometimes higher (Figs. 7a,c).

Fluvial gullies tend to have a wider range of $E q$ and lower values of $E q$ compared to debris flow gullies with martian gullies overlapping with both (Figs. 7b,d). Fluvial gullies tend to have lower debris apron slope and alcove slope compared to debris flow gullies, with martian gullies overlapping with both (Figs. 7a,b,d). The martian gullies overlap with both the fluvial and debris flow data in almost all cases (Figs. 7b-d), with the notable exception that, for any given debris apron slope (Fig. 8a), martian gullies tend to have a lower concavity (i.e., lower value of $\mathrm{Cl}$, than either fluvial, or debris flow gullies).

\subsection{Analysis of different martian gully alcove types}

The canonical discriminant functions calculated to separate terrestrial fluvial and debris flow gullies (coefficient A1) were applied to the five different alcove-type groups for martian gullies. This analysis was performed to investigate whether visually separable attributes also carried a morphological signature. Figure 9 shows the resulting boxplots. Gullies with alcoves cut back into the bedrock ("rockwall") are more similar to terrestrial debris flow gullies, and polar-pit "bouldery" alcoves are more similar to terrestrial fluvial gullies. The alcoves which are open at the top ("open") and those that form a cuspate scarp within the host-slope ("cuspate") both fall between the two endmembers, but sit towards the fluvial end.

Another approach is to perform a further canonical discriminant analysis using only the different martian alcove groups as an input - canonical analysis C. Table 6 shows the canonical function coefficients and Fig. 10 the associated scatter plot. In agreement with what we inferred from Fig. 9, canonical analysis $C$ reveals that the rockwall type and bouldery types are distinct both from one another, and also from the other two types, but the open and cuspate types cannot be separated. Figure 9 shows that the rockwall type is distinct from the others in terms of slope parameters and concavity index $(\vartheta)$ and eroded area $\left(A_{\text {ero }}\right)$. The boulder type is separable in terms of $\mathrm{Cl}$ and position 
plotted against debris apron slope, for the different alcove types. Rockwall types are systematically less concave than cuspate or open types. Rockwall types have the highest slopes and bouldery types the lowest slopes with the open and cuspate types falling between them.

\section{$4537 . \quad$ Discussion}

\section{$454 \quad$ 7.1. Comparison to previous work on fluvial and debris flow long profiles on Earth}

455 The very similar weighting of the different parameters used to separate debris flow from fluvial gullies on Earth in canonical discriminant analysis A, shows that each of them has an important role to play in separating the two groups. We have gone beyond previous research by explicitly comparing profiles formed by these two processes and by taking into account a range of slope and gradient parameters, but our results are broadly consistent with the previous interpretation of process from long-profiles in several ways. First, many authors have quoted that alluvial fans dominated by debris flows are steeper than those dominated by overland flow (e.g., Blair, 1999) and debris flow processes are generally accepted to occur on steeper slopes (Lague and Davy, 2003; Stock and Dietrich, 2006). Second, we have found that debris flow gullies tend to have steeper gradients, both overall, and in each of the debris apron, channel and alcove sections individually (Table 6 and Fig. 8). Finally, although concavity and position of basal concavity are more difficult to compare, visual comparison of individual published profile measurements reveals that debris flow gullies tend to have a basal concavity located in the downstream portion, and have a lower concavity (straighter profile), than fluvial ones (Ballantyne and Benn, 1994; Church et al., 1979; Larsson, 1982). We also find this to be the case for our data. For each of our three different measures of concavity, debris flows are less concave than fluvial gullies (Table 6 and Fig. 8) and the basal concavity for debris flows is located, in general, nearer the distal end, whereas it is more towards the proximal end in fluvial gullies. 
473 If we compare the concavity measurements we have made of long-profiles on Earth with published

474 data, we find that they are consistent with those found by other workers for larger systems. Goldrick

475 and Bishop (2007), for example, reported concavity index $(\theta)$ values of $0.31-1$ for convex-up stream

476 profiles in the Lachlan River catchment in SE Australia. Our data have equivalent magnitude, but

477 opposite sign, because our profiles are mostly concave-up in shape. Phillips and Lutz (2008) reported values of $\mathrm{Cl}$ between 0.027 to -0.109 for fluvial tributaries and 0.89 to -0.39 for full river profiles where both systems were in disequilibrium. The $\mathrm{Cl}$ values for our profiles (Table 6) fall within the range for the full fluvial systems (i.e., have much less extreme positive and negative values), but were more concave (values of $\mathrm{Cl}$ up to 0.43 ) than the tributaries studied by Phillips and Lutz (2008). Only in the martian examples did we come across any profiles that were convex in terms of $\mathrm{Cl}$, whereas this was a common feature in the tributary profiles of Phillips and Lutz (2008). Demoulin (1998) found erosion area $\left(A_{\text {ero }}\right)$ values between 0 and 0.57 , and values of the position of the maximal concavity $(E q)$ spanning $0.08-0.59$ for rivers in Belgium. For our data, we have equivalent values of $A_{\text {ero, }}$ but some of our data have higher values of Eq (especially for the debris flow and martian gullies).

Overall, the comparison of our concavity indices with those in the published literature reveal that the fluvial gully profiles that we have studied on Earth have, despite being smaller in scale, the typical concave-up profile traditionally associated with fluvial processes (Hack, 1957). The magnitude of $\mathrm{Cl}$ and concavity index $(\vartheta)$ of our fluvial profiles is smaller compared with full fluvial systems showing that our fluvial profiles would be classed as immature or non-equilibrium systems. Within this framework, the debris flow gullies we have studied would be considered as systems with even greater immaturity and/or non-equilibria. This is no surprise for the Earth data as these gullies are forming on recently exposed landscapes (recently de-glaciated, uplifted, or erupted, see Section 2.1).

\subsection{Comparing Gullies on Earth and Mars}


We have found that long profile dimensions and parameters are similar between gullies on Mars and gully profiles generated by debris flow and fluvial processes on Earth. Martian gullies are slightly larger in terms of spatial scale, a fact that can be explained simply by the availability of a larger number of hillslopes of that scale, generated through impact cratering. Undisrupted hillslopes on Earth rarely exceed a kilometre in height or $2 \mathrm{~km}$ lateral extent (Evans, 2003). In terms of profile parameters, martian gullies differ from fluvial gullies in terms of concavity indices, and from debris flow gullies in terms of slope/gradient indices. The fact that there is little separation between these different long-profiles is surprising, given that these features are found on different planets, both because of the different substrate types, and also because, on Earth, geomorphology is influenced by biological systems, which are not present on Mars.

The stream power law contains a gravity term which controls the erosional shear-stress exerted on the stream-bed. On Mars this would be $\sim 1 / 3$ that experienced on Earth, leading to equilibrium and detachment-limited fluvial profiles being $\sim 3$ times steeper at a given drainage area for those on Earth (Conway et al., 2011). Such an adjustment would be valid in the case of a fully mature equilibrium fluvial system, but gullies are located on steep slopes where the flow shear stress does not necessarily dominate the morphology-forming process. In fact, the fluvial gullies we have included from Earth are inevitably influenced by creep, sheetflow, landsliding and rockfall. Therefore, we believe that such a gravity adjustment cannot be applied to long profiles including first-order catchments. For dry granular flow the difference of gravity between Earth and Mars makes no difference to the equilibrium long-profile (Atwood-Stone and McEwen, 2013). Debris flows are a special case of granular flow, where the interstitial fluid is water, so the governing equations can be divided into grain-grain interactions and a fluid dynamics part. The gravity scaling for debris flow processes suffers from similar complications of assumed equilibrium as for fluvial flows, and in addition several different formulations exist for the rheology of debris flows and thus for the relation between bed shear stress and distance travelled (Ancey, 2007; Iverson, 1997). If the bed of the flow is non-cohesive then there is no gravity dependence, whereas if the bed of the flow is cohesive then 
profiles should be $\sim 3$ times steeper, as the dependence of shear stress on slope has a similar

524 formulation to that for fluvial flows (Ancey, 2007; Papa et al., 2004). On-balance we argue that differences in substrate type and in biota would dominate over any physical differences between these systems and that gravity-scaling is not required to successfully compare these long profile data.

\subsection{Are there different gully types on Mars?}

We have found that gullies with morphologically different alcove types (Figs. 9 and 10) can, using discriminant analysis, be separated from one another in terms of their profile parameters. These differences in profile parameters between morphologically distinct gully alcoves types could be due to the inherent difference in the morphological heritage of the slopes (Hobbs et al., 2014, 2013), or to a difference in the frequency, intensity and/or type of gully forming process. Because the cuspate, open and rockwall types are widely distributed in terms of latitude and longitude, and occur on different host-slopes (crater walls, hills, valleys), the difference between them cannot be attributed to a systematic difference in their inherited slope-forms. In other words the differences between these gully-types cannot be attributed to geological factors, such as rock-type, but could be attributable to differences in surface mantling. The same cannot be said for the bouldery type, which occur exclusively in polar pits - here their form could be entirely inherited from their host slope.

Cuspate and open alcove types have strong similarities in terms of profile parameters, which may suggest similar formation processes. In previous work, these two types of alcoves have been associated with "pasted-on terrain" or the ice-rich latitude dependant mantle (LDM; Christensen, 2003, Dickson et al., 2015, Levy et al., 2009, Head et al., 2008, Schon et al., 2009 and Raack et al., 2012). Hence it could be this difference in substrate that sets these alcove types apart from the others in Fig. 10. Conway and Balme (2014) suggested that the volumetric disparity between the alcove and fan of gullies hosted completely within the LDM is neatly explained by an LDM-ice- 
a flow would be dilute and this would explain the cuspate/open type's closer affinity to fluvial terrestrial gullies in Fig. 9. Indeed, if we examine the depositional fans of those gullies with cuspate/open alcove types with low values of canonical function A1 (indicative of fluvial processes on Earth), there are some notable similarities (Fig. 12). These include: sinuous channels cut into fan surfaces with no obvious levees, fan-deposits with no obvious topographic relief, which infill topographic lows and cuff-off channel segments. Note that not all gullies with a low canonical function A1 (indicating fluvial processes) shared these visual properties. In some cases this was because the image quality would be too poor to identify these features (if they existed). However, lack of such features in the other cases is not proof of absence of the process in the past. Such

557 features are small-scale and easily removed or degraded (e.g., overprinted by ripples), making visual 558 feature-identification difficult. De Haas et al. (2013) noted the rapid degradation of boulders on 559 gully-fans, and such fast rates of degradation could easily lead to rapid disappearance of such finescale depositional morphologies.

Rockwall chutes are distinctly separable from cuspate/open types and have the steepest and most linear profiles (Fig. 11), overlapping with debris flow profiles on Earth. This presents two possible explanations: (1) that the bedrock contributes a dry mass wasting component to a fluvial signal, which tends to make the profile more linear, or (2) that debris flow is the dominant process in forming this type of gully. The second inference is supported by the fact that the long profiles of these gullies are most similar to terrestrial debris flow gullies (Fig. 9) and that their fan morphology shares a number of attributes with terrestrial debris flow deposits, as shown in Fig. 12. These include multiple overlapping fans/lobes with topographic expression, cut-off and backfilled channel segments, occasional levees and broad channels with lobate overflow deposits. Not all gullies with a high canonical function A1 (indicating debris flow processes) shared these visual properties and the 
supports this link between the rockwall alcove morphology and debris flow process. This association implies that bedrock cropping out in the alcove promotes debris flow behaviour in gullies.

The bouldery alcove type, which is synonymous with polar pit gullies, shows affinity to terrestrial fluvial gullies. These gullies are thought to be evolving at the present day under $\mathrm{CO}_{2}$ sublimation driven processes (Raack et al., 2015). Without further information on the physics of sediment transport by $\mathrm{CO}_{2}$ gas supported flows, we cannot comment on whether they are likely or not to produce long-profiles similar to the terrestrial fluvial gullies included in our study. We argue that gullies have actively graded these pit walls, rather than simply superposing the pre-existing profile structure, because (1) gully deposits extend laterally across the whole slope, implying the whole slope has been affected by gully-processes, and (2) if the pit-slopes were originally formed by collapse (Tanaka and Kolb, 2001), they should lie at the angle of repose of $\sim 30^{\circ}$ (Kleinhans et al., 2011) along their whole long profile, but alcove slopes are never more than $24^{\circ}$ and the channel and debris aprons have shallower slopes.

\section{Conclusions}

The stereo point matching method developed by Kreslavsky (2008) has been shown to be particularly useful for collecting a large quantity of simple elevation data rapidly, without the onerous requirement of producing full Digital Terrain Models, and we have shown that it is sufficiently accurate to produce reliable results when analysing martian gully long profiles. We have also shown that, for small kilometre-scale gullies on Earth, the long profile slope and concavity properties are different for those gullies formed by debris flow compared to those formed by fluvial processes. Gullies on Mars overlap in terms of long profile properties with fluvial gullies and debris flow gullies on Earth. Gullies on Earth and Mars are both visually similar and similar in terms of scale, slope and concavity. Discriminant analysis indicates that long profiles of gullies on Mars have slightly more affinity with fluvial gullies than debris flow gullies on Earth. This provides additional evidence

597 that gullies on Mars are formed by a process that is similar to gully formation on Earth, which 
inherently involves liquid water. Gullies with different alcove types on Mars have different profile properties. We found two distinct groups: (1) polar pit gullies $\left(\sim 70^{\circ} \mathrm{S}\right)$ are closest in form to fluvial gullies on Earth, (2) gullies with rockwall alcoves that incise up to the crater rim are most similar to debris flow gullies on Earth. The other alcove types, consisting of gullies which start mid-slope and are associated with pasted-on terrain (or latitude dependant mantle), have intermediate properties, but are skewed towards fluvial gullies. This supports the possibility that gullies on Mars may have multiple formation origins, just as on Earth. Further this work suggests that the presence (or absence) of mantling units could be one of the factors controlling the dominant process in martian gullies and that a bedrock alcove promotes the occurrence of debris flow behaviour on Mars.

\section{Acknowledgements}

We thank Jay Dickson and Tanya Harrison for their insightful reviews that helped to improve the manuscript. Thanks to Colin Dundas on information about the MRO orbit and HiRISE pointing. These analyses would not have been possible without data from the Natural Environment Research Council (NERC) Airborne Research and Survey Facility project IPY07-04, or NERC Geophysical Equipment Facility loan number 871 , or funding from a NERC studentship. We thank Alvaro Marquez, Tatiana Isquierdo and Sam Hammond for their assistance in the field. Chris Okubo from the USGS was responsible for generating the gridded HiRISE elevation data for Mars at sites $\mathrm{G}$ and $\mathrm{H}$, enabling us to test the manual matching method. MRB and SJC acknowledge funding from the Leverhulme Trust (grant number RPG-397). MCT acknowledges funding from the Australian Research Council via the Australian Laureate Fellowship program. This is PSI contribution number xxx.

\section{References cited:}

Allison, R.J., Higgitt, D.L., 1998. Slope form and associations with ground boulder cover in arid environments, northeast Jordan. Catena 33, 47-74.

Ancey, C., 2007. Plasticity and geophysical flows: A review. J. Non-Newton. Fluid Mech. 142, 4-35. Ancochea, E., Hernán, F., Huertas, M.J., Brändle, J.L., Herrera, R., 2006. A new chronostratigraphical and evolutionary model for La Gomera: Implications for the overall evolution of the Canarian Archipelago. J. Volcanol. Geotherm. Res. 157, 271-293. 
Anderson, J.A., S. C. Sides, Soltesz, D.L., Sucharski, T.L., Becker, K.J., 2004. Modernization of the integrated software for imagers and spectrometers. Lunar Planet. Sci. Conf. 35, \#2039.

Aston, A.H., Conway, S.J., Balme, M.R., 2011. Identifying Martian gully evolution, in: Balme, M., Bargery, A.S., Gallagher, C., Gupta, S. (Eds.), Martian Geomorphology. The Geological Society of London, pp. 151-169.

Atwood-Stone, C., McEwen, A.S., 2013. Avalanche slope angles in low-gravity environments from active Martian sand dunes. Geophys. Res. Lett. 40, 2929-2934. doi:10.1002/grl.50586

Ballantyne, C.K., Benn, D.I., 1994. Paraglacial Slope Adjustment and Resedimentation Following Recent Glacier Retreat, Fabergstolsdalen, Norway. Arct Alp Res 26, 255-269.

Balme, M., Mangold, N., Baratoux, D., Costard, F., Gosselin, M., Masson, P., Pinet, P., Neukum, G., 2006. Orientation and distribution of recent gullies in the southern hemisphere of Mars: Observations from High Resolution Stereo Camera/Mars Express (HRSC/MEX) and Mars Orbiter Camera/Mars Global Surveyor (MOC/MGS) data. J. Geophys. Res. Planets 111, doi:10.1029/2005JE002607.

Blair, T.C., 1999. Cause of dominance by sheetflood vs. debris-flow processes on two adjoining alluvial fans, Death Valley, California. Sedimentology 46, 1015-1028.

Brardinoni, F., Hassan, M.A., 2006. Glacial erosion, evolution of river long profiles, and the organization of process domains in mountain drainage basins of coastal British Columbia. J. Geophys. Res. F Earth Surf. 111, doi:10.1029/2005JF000358.

Cedillo-Flores, Y., Treiman, A.H., Lasue, J., Clifford, S.M., 2011. CO2 gas fluidization in the initiation and formation of Martian polar gullies. Geophys. Res. Lett. 38, doi:10.1029/2011GL049403. doi:10.1029/2011GL049403

Christensen, P.R., 2003. Formation of recent martian gullies through melting of extensive water-rich snow deposits. Nature 422, 45-48.

Church, M., Stock, R.F., Ryder, J.M., 1979. Contemporary Sedimentary Environments on Baffin Island, Nwt, Canada - Debris Slope Accumulations. Arct. Alp. Res. 11, 371-402.

Coe, J.A., Godt, J.W., Henceroth, A.J., 2002. Debris Flows along the Interstate 70 Corridor, Floyd Hill to the Arapahoe Basin Ski Area, Central Colorado - A Field Trip Guidebook.

Conway, S.J., Balme, M., Murray, J.B., Towner, M.C., Okubo, C., Grindrod, P.M., 2011. The determination of martian gully formation processes by slope-area analysis., in: Balme, M., Bargery, A.S., Gallagher, C., Gupta, S. (Eds.), Martian Geomorphology. The Geological Society of London, pp. 171-201.

Conway, S.J., Decaulne, A., Balme, M.R., Murray, J.B., Towner, M.C., 2010. A new Approach to Estimating Hazard posed by Debris Flows in the Westfjords of Iceland. Geomorphology 114, 556-572. doi:10.1016/j.geomorph.2009.08.015

Costard, F., Forget, F., Mangold, N., Peulvast, J.P., 2002. Formation of recent Martian debris flows by melting of near-surface ground ice at high obliquity. Science 295, 110-113. doi:10.1126/science.1066698

Crippen, J.R., 1979. Potential hazards from floodflows and debris movement in the Furnace Creek area, Death Valley National Monument, California-Nevada (USGS Open-File Report No. 79991).

De Haas, T., Hauber, E., Kleinhans, M.G., 2013. Local late Amazonian boulder breakdown and denudation rate on Mars. Geophysical Research Letters n/a-n/a. doi:10.1002/grl.50726

Demoulin, A., 1998. Testing the tectonic significance of some parameters of longitudinal river profiles: the case of the Ardenne (Belgium, NW Europe). Geomorphology 24, 189-208.

Dickson, J.L., Head, J.W., Goudge, T.A., Barbieri, L., 2015. Recent climate cycles on Mars: Stratigraphic relationships between multiple generations of gullies and the latitude dependent mantle. Icarus 252, 83-94. doi:10.1016/j.icarus.2014.12.035

Dickson, J.L., Head, J.W., Fassett, C.I., 2012. Patterns of accumulation and flow of ice in the midlatitudes of Mars during the Amazonian. Icarus 219, 723-732. doi:10.1016/j.icarus.2012.03.010 
Dickson, J.L., Head, J.W., Kreslavsky, M., 2007. Martian gullies in the southern mid-latitudes of Mars: Evidence for climate-controlled formation of young fluvial features based upon local and global topography. Icarus 188, 315-323.

Evans, I.S., 2003. Scale-specific landforms and aspects of the land surface, in: Concepts and Modelling in Geomorphology: International Perspectives. TERRAPUB, Tokyo.

Gaddis, L., Anderson, J., Becker, K., Becker, T., Cook, D., Edwards, K., Eliason, E., Hare, T., Kieffer, H., Lee, E.M., 1997. An overview of the integrated software for imaging spectrometers (ISIS). Lunar Planet. Sci. Conf. 28, \#1226.

Gallagher, C., Balme, M.R., Conway, S.J., Grindrod, P.M., 2011. Sorted clastic stripes, lobes and associated gullies in high-latitude craters on Mars: Landforms indicative of very recent, polycyclic ground-ice thaw and liquid flows. Icarus 211, 458-471. doi:10.1016/j.icarus.2010.09.010

Godt, J.W., Coe, J.A., 2007. Alpine debris flows triggered by a 28 July 1999 thunderstorm in the central Front Range, Colorado. Geomorphology 84, 80-97.

Goldrick, G., Bishop, P., 2007. Regional analysis of bedrock stream long profiles: Evaluation of Hack's SL form, and formulation and assessment of an alternative (the DS form). Earth Surf. Process. Landf. 32, 649-671.

Hack, J.T., 1957. Studies of longitudinal stream profiles in Virginia and Maryland. US Geol. Surv. Prof. Pap. 294-B, 45-97.

Hanks, T.C., Webb, R.H., 2006. Effects of tributary debris on the longitudinal profile of the Colorado River in Grand Canyon. J. Geophys. Res. F Earth Surf. 111, doi:10.1029/2004JF000257.

Harrison, T.N., Osinski, G.R., Tornabene, L.L., 2014. Global Documentation of Gullies with the Mars Reconnaissance Orbiter Context Camera (CTX) and Implications for Their Formation. Lunar Planet. Sci. Conf. 45, \#1777.

Head, J.W., Marchant, D.R., Kreslavsky, M.A., 2008. Formation of gullies on Mars: Link to recent climate history and insolation microenvironments implicate surface water flow origin. P. Natl. Acad. Sci. USA 105, 13258-13263.

Head, J.W., Mustard, J.F., Kreslavsky, M.A., Milliken, R.E., Marchant, D.R., 2003. Recent ice ages on Mars. Nature 426, 797-802. doi:10.1038/nature02114

Hecht, M.H., 2002. Metastability of liquid water on Mars. Icarus 156, 373-386.

Heldmann, J.L., Toon, O.B., Pollard, W.H., Mellon, M.T., Pitlick, J., McKay, C.P., Andersen, D.T., 2005. Formation of Martian gullies by the action of liquid water flowing under current Martian environmental conditions. J Geophys Res-Planets 110, doi:10.1029/2004JE002261.

Hobbs, S.W., Paull, D.J., Clarke, J.D.A., 2013. The influence of slope morphology on gullies: Terrestrial gullies in Lake George as analogues for Mars. Planet. Space Sci. 81, 1-17. doi:10.1016/j.pss.2012.10.009

Hobbs, S.W., Paull, D.J., Clark, J.D.A., 2014. A comparison of semiarid and subhumid terrestrial gullies with gullies on Mars: Implications for Martian gully erosion. Geomorphology 204, 344-365. doi:10.1016/j.geomorph.2013.08.018

Hugenholtz, C.H., 2008. Frosted granular flow: A new hypothesis for mass wasting in martian gullies. Icarus 197, 65-72.

Iverson, R.M., 1997. The physics of debris flows. Rev Geophys 35, 245-296.

Johnsson, A., Reiss, D., Hauber, E., Hiesinger, H., Zanetti, M., 2014. Evidence for very recent meltwater and debris flow activity in gullies in a young mid-latitude crater on Mars. Icarus 235, 37-54. doi:10.1016/j.icarus.2014.03.005

Kleinhans, M.G., Markies, H., de Vet, S.J., in 't Veld, A.C., Postema, F.N., 2011. Static and dynamic angles of repose in loose granular materials under reduced gravity. J. Geophys. Res. Planets 116, doi:10.1029/2011JE003865. doi:10.1029/2011JE003865

Kneissl, T., Reiss, D., van Gasselt, S., Neukum, G., 2010. Distribution and orientation of northernhemisphere gullies on Mars from the evaluation of HRSC and MOC-NA data. Earth Planet. Sci. Lett. 294, 357-367. doi:j.epsl.2009.05.018 
Kreslavsky, M.A., 2008. Slope Steepness of Channels and Aprons: Implications for Origin of Martian Gullies. Workshop Martian Gullies, Workshop on Martian Gullies 2008, abs.\#1301.

Lague, D., Davy, P., 2003. Constraints on the long-term colluvial erosion law by analyzing slope-area relationships at various uplift rates in the Siwaliks Hills (Nepal). J. Geophys. Res. B Solid Earth 108, doi:10.1029/2002JB001893.

Lanza, N.L., Meyer, G.A., Okubo, C.H., Newsom, H.E., Wiens, R.C., 2010. Evidence for debris flow gully formation initiated by shallow subsurface water on Mars. Icarus 205, 103-112.

Larsson, S., 1982. Geomorphological Effects on the Slopes of Longyear Valley, Spitsbergen, after a Heavy Rainstorm in July 1972. Geogr Ann Ser -Phys Geogr 64, 105-125.

Levy, J., Head, J.W., Marchant, D.R., 2010. Concentric crater fill in the northern mid-latitudes of Mars: Formation processes and relationships to similar landforms of glacial origin. Icarus 209, 390-404. doi:10.1016/j.icarus.2010.03.036

Levy, J.S., Head, J.W., Dickson, J.L., Fassett, C.I., Morgan, G.A., Schon, S.C., 2010. Identification of gully debris flow deposits in Protonilus Mensae, Mars: Characterization of a water-bearing, energetic gully-forming process. Earth Planet. Sci. Lett., Mars Express after 6 Years in Orbit: Mars Geology from Three-Dimensional Mapping by the High Resolution Stereo Camera (HRSC) Experiment 294, 368-377. doi:10.1016/j.epsl.2009.08.002

Levy, J.S., Head, J.W., Marchant, D.R., Dickson, J.L., Morgan, G.A., 2009. Geologically recent gullypolygon relationships on Mars: Insights from the Antarctic dry valleys on the roles of permafrost, microclimates, and water sources for surface flow. Icarus 201, 113-126.

Llanes, P., Herrera, R., Gómez, M., Muñoz, A., Acosta, J., Uchupi, E., Smith, D., 2009. Geological evolution of the volcanic island La Gomera, Canary Islands, from analysis of its geomorphology. Mar. Geol. 264, 123-139.

Malin, M.C., Edgett, K.S., 2000. Evidence for recent groundwater seepage and surface runoff on Mars. Science 288, 2330-2335. doi:10.1126/science.288.5475.2330

Mangold, N., Mangeney, A., Migeon, V., Ansan, V., Lucas, A., Baratoux, D., Bouchut, F., 2010. Sinuous gullies on Mars: Frequency, distribution, and implications for flow properties. J Geophys Res 115, doi:10.1029/2009je003540. doi:10.1029/2009je003540

Mao, L., Cavalli, M., Comiti, F., Marchi, L., Lenzi, M.A., Arattano, M., 2009. Sediment transfer processes in two Alpine catchments of contrasting morphological settings. J. Hydrol. 364, 88-98.

Marquez, A., de Pablo, M.A., Oyarzun, R., Viedma, C., 2005. Evidence of gully formation by regional groundwater flow in the Gorgonum-Newton region (Mars). Icarus 179, 398-414.

McLachlan, G.J., 2004. Discriminant Analysis and Statistical Pattern Recognition. John Wiley \& Sons.

Milliken, R.E., Mustard, J.F., Goldsby, D.L., 2003. Viscous flow features on the surface of Mars: Observations from high-resolution Mars Orbiter Camera (MOC) images. J Geophys Res 108, doi:10.1029/2002JE002005.

Norðdalh, H., 1990. Late Weichselian and early Holocene deglaciation history of Iceland. Jökull 40, 27-50.

Papa, M., Egashira, S., Itoh, T., 2004. Critical conditions of bed sediment entrainment due to debris flow. Nat Hazards Earth Syst Sci 4, 469-474. doi:10.5194/nhess-4-469-2004

Parsons, R.A., Nimmo, F., 2010. Numerical modeling of Martian gully sediment transport: Testing the fluvial hypothesis. J Geophys Res 115, doi:10.1029/2009JE003517. doi:10.1029/2009je003517

Phillips, J.D., Lutz, J.D., 2008. Profile convexities in bedrock and alluvial streams. Geomorphology 102, 554-566.

Raack, J., Reiss, D., Appéré, T., Vincendon, M., Ruesch, O., Hiesinger, H., 2015. Present-Day Seasonal Gully Activity in a South Polar Pit (Sisyphi Cavi) on Mars. Icarus in press. doi:j.icarus.2014.03.040

Raack, J., Reiss, D., Hiesinger, H., 2012. Gullies and their relationships to the dust-ice mantle in the northwestern Argyre Basin, Mars. Icarus 219, 129-141. doi:10.1016/j.icarus.2012.02.025 
Reiss, D., van Gasselt, S., Neukum, G., Jaumann, R., 2004. Absolute dune ages and implications for the time of formation of gullies in Nirgal Vallis, Mars. J Geophys Res-Planets 109, doi:10.1029/2004JE002251.

Rowantree, K.M., 1991. Morphological Characteristics of Gully Networks and their Relationship to Host Materials, Baringo District, Kenya. GeoJournal 23, 19-27.

Schon, S.C., Head, J.W., 2009. Terraced Cutbanks and Longitudinal Bars in Gully Channels on Mars: Evidence for Multiple Episodes of Fluvial Transport. Lunar Planet. Sci. Conf. 40, \# 1691.

Schon, S.C., Head, J.W., Fassett, C.I., 2009. Unique chronostratigraphic marker in depositional fan stratigraphy on Mars: Evidence for ca. 1.25 Ma gully activity and surficial meltwater origin. Geology 37, 207-210. doi:10.1130/g25398a.1

Souness, C., Hubbard, B., Milliken, R.E., Quincey, D., 2012. An inventory and population-scale analysis of Martian glacier-like forms. Icarus 217, 243-255. doi:10.1016/j.icarus.2011.10.020

Stock, J.D., Dietrich, W.E., 2006. Erosion of steepland valleys by debris flows. Bull. Geol. Soc. Am. $118,1125-1148$.

Tanaka, K.L., Kolb, E.J., 2001. Geologic History of the Polar Regions of Mars Based on Mars Global Surveyor Data: I. Noachian and Hesperian Periods. Icarus 154, 3-21. doi:10.1006/icar.2001.6675

Treiman, A.H., 2003. Geologic settings of Martian gullies: Implications for their origins. J. Geophys. Res. Planets 108, doi:10.1029/2002JE001900. doi:10.1029/2002JE001900

Workman, J.B., Menges, C.M., Page, W.R., Taylor, E.M., Ekren, E.B., Rowley, P.D., Dixon, G.L., Thompson, R.A., Wright, L.A., 2002. Geologic map of the Death Valley ground-water model area, Nevada and California. 
Table 1: Summary table for the study sites on Earth. ${ }^{a}$

\begin{tabular}{|c|c|c|c|c|c|c|c|c|}
\hline Location & Date Flown & Data Source & $\begin{array}{l}\text { Approx. } \\
\text { precipitation } \\
\text { (mm/year) }\end{array}$ & $\begin{array}{l}\text { Landscape- } \\
\text { type }\end{array}$ & Latitude & Longitude & $\begin{array}{l}\text { Average } \\
\text { elevation } \\
\text { (m) }\end{array}$ & $\begin{array}{c}\text { Relief } \\
\text { (m) }\end{array}$ \\
\hline $\begin{array}{l}\text { San Jacinto } \\
\text { Fault }\end{array}$ & mid 2005 & $\begin{array}{c}\text { NCALM B4 } \\
\text { Project }\end{array}$ & 150 & desert & $\begin{array}{c}33^{\circ} 25^{\prime} \\
58.55^{\prime \prime} \mathrm{N}\end{array}$ & $\begin{array}{c}116^{\circ} 28^{\prime} \\
57.55^{\prime \prime} \mathrm{W}\end{array}$ & 597 & 677 \\
\hline $\begin{array}{c}\text { Death Valley } \\
\text { California }\end{array}$ & $28 / 02 / 2005$ & NCALM & $<85$ & desert & $\begin{array}{c}39^{\circ} 38^{\prime} \\
01.77^{\prime \prime} \mathrm{N}\end{array}$ & $\begin{array}{c}105^{\circ} 49^{\prime} \\
13.88^{\prime \prime} \mathrm{W}\end{array}$ & 3664 & 1345 \\
\hline $\begin{array}{c}\text { Front Range, } \\
\text { Colorado }\end{array}$ & 29/09/2005 & NCALM & 600 & periglacial & $\begin{array}{c}37^{\circ} 04^{\prime} \\
28.50^{\prime \prime} \mathrm{N}\end{array}$ & $\begin{array}{c}117^{\circ} 26^{\prime} \\
37.60^{\prime \prime} \mathrm{W}\end{array}$ & 258 & 854 \\
\hline $\begin{array}{l}\text { Westfjords, } \\
\text { Iceland }\end{array}$ & $05 / 08 / 2007$ & ARSF & 700 & periglacial & $\begin{array}{c}66^{\circ} 04^{\prime} \\
13.20^{\prime \prime} \mathrm{N}\end{array}$ & $\begin{array}{c}023^{\circ} 07^{\prime} \\
14.19^{\prime \prime} \mathrm{W}\end{array}$ & 271 & 807 \\
\hline $\begin{array}{l}\text { La Gomera, } \\
\text { Canary } \\
\text { Islands }\end{array}$ & $\mathrm{n} / \mathrm{a}$ & GRAFCAN & $\sim 200$ & $\begin{array}{l}\text { Semi-arid to } \\
\text { arid }\end{array}$ & $\begin{array}{c}28^{\circ} 07^{\prime} \\
04.15^{\prime \prime} \mathrm{N}\end{array}$ & $\begin{array}{c}17^{\circ} 20^{\prime} 4.94^{\prime \prime} \\
\mathrm{W}\end{array}$ & 467 & 991 \\
\hline
\end{tabular}

$803{ }^{a}$ Average elevation is given relative to datum, for A-D this is NAD 1983 and for Site $E$ this is WGS

804 1984, in both cases the difference between the datum and sea level is approximately $60 \mathrm{~m}$.

805 Abbreviations: NCALM - National Center for Airborne Laser Mapping supported by the USA's

806 National Science Foundation, ARSF - Airborne Research and Survey Facility supported by the UK Natural Environment Research Council. 


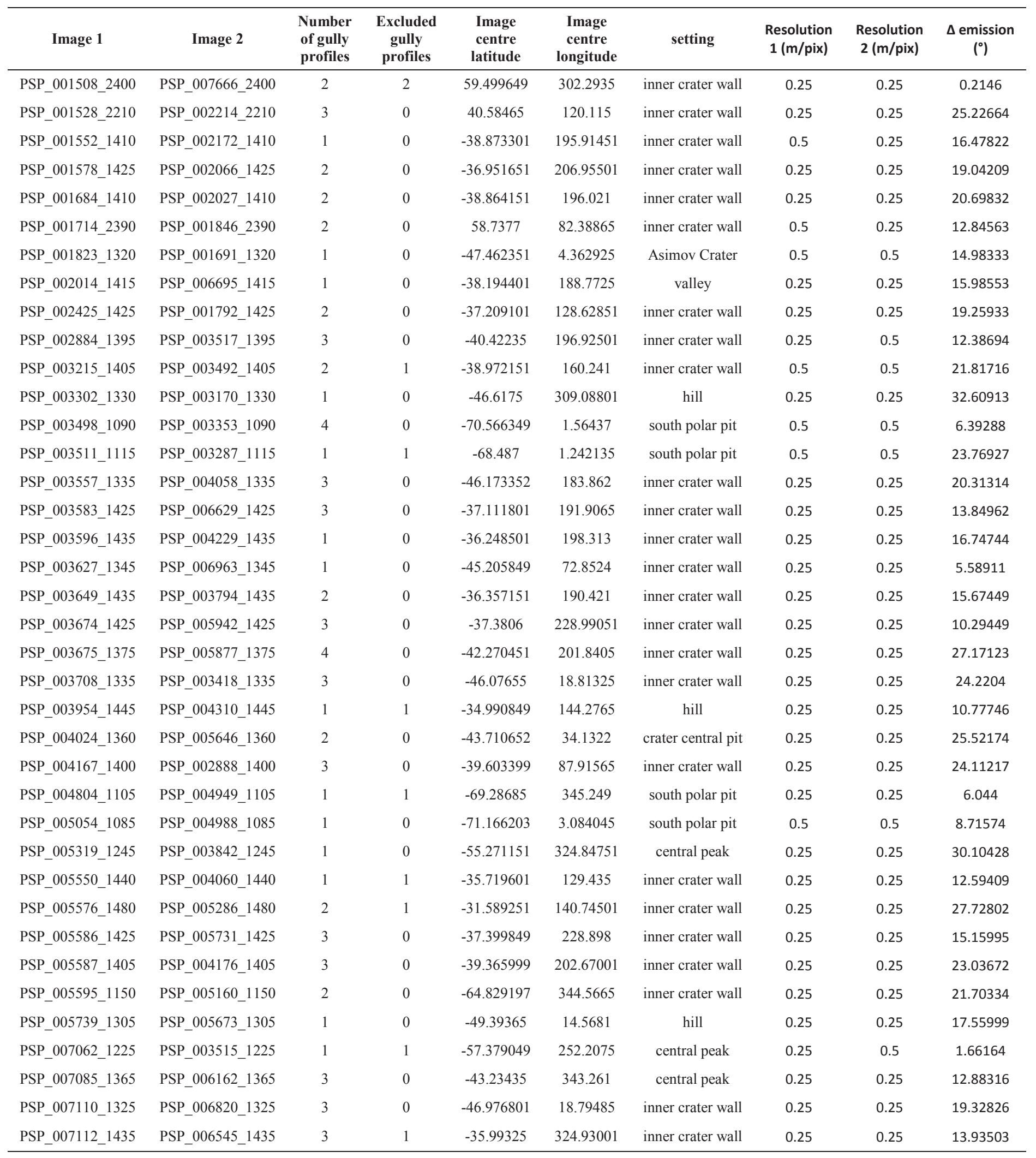


811 Table 3: Summary table for the martian HiRISE elevation datasets used to compare to the point 812 elevation data extracted using the Kreslavsky (2008) method. ${ }^{a}$

\begin{tabular}{|c|c|c|c|c|c|}
\hline Site & HiRISE image pair & Latitude & Longitude & $\begin{array}{l}\text { Average elevation } \\
\text { (m) }\end{array}$ & Relief (m) \\
\hline $\mathrm{F}$ & $\begin{array}{l}\text { PSP_001714_1415 } \\
\text { PSP_001846_1415 }\end{array}$ & $-38.4^{\circ}$ & $96.8^{\circ}$ & -2648 & 1124 \\
\hline G & $\begin{array}{l}\text { PSP_004060_1440 } \\
\text { PSP_005550_1440 }\end{array}$ & $-35.7^{\circ}$ & $129.4^{\circ}$ & 300 & 1205 \\
\hline $\mathrm{H}$ & $\begin{array}{l}\text { PSP_003418_1335 } \\
\text { PSP_003708_1335 }\end{array}$ & $-46.1^{\circ}$ & $18.8^{\circ}$ & 595 & 687 \\
\hline $\mathrm{J}$ & $\begin{array}{l}\text { PSP_003674_1425 } \\
\text { PSP_005942_1425 }\end{array}$ & $-37.4^{\circ}$ & $229.0^{\circ}$ & 1904 & 961 \\
\hline
\end{tabular}

813 average elevation is given relative to the Mars datum, as defined from the MOLA gridded dataset.

814 The average elevation has been estimated from the MOLA dataset and relief from the HiRISE DEMs. 
Table 4: Differences between profile parameters for stereo-point analysis and DEM analysis.

\begin{tabular}{|c|c|c|c|c|c|}
\hline & Site F & Site $\mathbf{J}$ & Site H & Site $\mathbf{H}$ & Site $\mathbf{G}$ \\
\hline Image 1 & PSP_001714_1415 & PSP_003674_1425 & PSP_003708_1335 & PSP_003708_1335 & PSP_005550_1440 \\
\hline Included in study & No & Yes & Yes & Yes & No \\
\hline Gully ID & 1 & 4 & 1 & 2 & 1 \\
\hline $\begin{array}{l}\text { Difference in total } \\
\text { length \% }\end{array}$ & -7.74 & -7.62 & -0.76 & -0.31 & -12.28 \\
\hline $\begin{array}{l}\text { Difference in total } \\
\text { height \% }\end{array}$ & -7.89 & -0.18 & 3.65 & 3.69 & 2.15 \\
\hline $\begin{array}{l}\text { Difference in } \\
\text { average channel } \\
\text { slope }\left({ }^{\circ}\right)\end{array}$ & $\mathrm{nm}$ & $\mathrm{nm}$ & 1.30 & 0.47 & 9.09 \\
\hline $\begin{array}{l}\text { Difference in Area } \\
\text { of Erosion }\left(A_{e r o}\right)\end{array}$ & -0.10 & 0.02 & 0.02 & 0.05 & 0.33 \\
\hline $\begin{array}{l}\text { Difference in } \\
\text { Relative Concavity } \\
\text { Index }(C I)\end{array}$ & -0.126 & 0.005 & 0.011 & 0.005 & 0.044 \\
\hline $\begin{array}{l}\text { Difference in } \\
\text { relative position of } \\
\text { maximal concavity } \\
(E q)\end{array}$ & 0.068 & -0.002 & -0.005 & 0.001 & 0.331 \\
\hline $\begin{array}{l}\text { Difference in } \\
\text { Concavity Index }(\theta)\end{array}$ & -0.30 & -0.01 & 0.01 & -0.03 & 0.23 \\
\hline $\begin{array}{l}\text { Difference in start- } \\
\text { end gradient }\end{array}$ & 0.02 & -0.05 & -0.01 & -0.01 & 0.01 \\
\hline Mean error value & 0.00 & -8.80 & 0.50 & 0.88 & -6.52 \\
\hline $\begin{array}{l}\text { Standard deviation } \\
\text { of error value }\end{array}$ & 36.12 & 2.92 & 1.10 & 6.01 & 126.77 \\
\hline
\end{tabular}

817 
818 Table 5: Summary of data for terrestrial fluvial, terrestrial debris flow and martian gully long profiles.

\begin{tabular}{|c|c|c|c|c|}
\hline & & $\begin{array}{l}\text { Terrestrial debris } \\
\text { flow }\end{array}$ & Terrestrial fluvial & Martian gullies \\
\hline \multirow{3}{*}{$\begin{array}{l}\text { Height drop over } \\
\text { profile (m) }\end{array}$} & range & $250-682$ & $75-841$ & $138-2082$ \\
\hline & median & 431.1 & 199.1 & 493.2 \\
\hline & count & 22 & 24 & 67 \\
\hline \multirow[t]{3}{*}{ Length of profile (m) } & range & $391-1336$ & $149-1843$ & $349-6380$ \\
\hline & median & 785.2 & 556 & 1269 \\
\hline & count & 22 & 24 & 67 \\
\hline \multirow[t]{3}{*}{ Gradient } & range & $-0.72--0.48$ & $-0.96--0.15$ & $-0.63--0.17$ \\
\hline & median & -0.5841 & -0.4415 & -0.3512 \\
\hline & count & 22 & 24 & 67 \\
\hline \multirow[t]{3}{*}{ Range in Slopes } & range & $8-41$ & $12-71$ & $7-85$ \\
\hline & median & 21.75 & 30.5 & 19.35 \\
\hline & count & 22 & 24 & 67 \\
\hline \multirow[t]{3}{*}{ Average alcove slope } & range & $27-42$ & $13-64$ & $16-40$ \\
\hline & median & 35.94 & 29.07 & 24.71 \\
\hline & count & 22 & 24 & 67 \\
\hline \multicolumn{2}{|c|}{ Average channel slope range } & $20-37$ & $7-34$ & $8-35$ \\
\hline & median & 30.27 & 21.14 & 17.73 \\
\hline & count & 21 & 23 & 67 \\
\hline \multirow{3}{*}{$\begin{array}{l}\text { Average debris apron } \\
\text { slope }\end{array}$} & range & $15-31$ & $3-24$ & $6-31$ \\
\hline & median & 21.93 & 8.603 & 13.87 \\
\hline & count & 22 & 15 & 67 \\
\hline \multirow[t]{3}{*}{ Concavity \#1 $\left(A_{\text {ero }}\right)$} & range & $0.15-0.54$ & $0.07-0.54$ & $0.02-0.77$ \\
\hline & median & 0.3651 & 0.3952 & 0.365 \\
\hline & count & 22 & 24 & 67 \\
\hline \multirow[t]{3}{*}{ Concavity \#2 (CI) } & range & $0.04-0.21$ & $0.02-0.43$ & $-0.16-0.3$ \\
\hline & median & 0.1527 & 0.2157 & 0.1642 \\
\hline & count & 22 & 24 & 67 \\
\hline \multirow[t]{3}{*}{ Concavity \#3 $(\theta)$} & range & $-0.56--0.07$ & $-1.11--0.04$ & $-0.86--0.02$ \\
\hline & median & -0.3776 & -0.5202 & -0.3886 \\
\hline & count & 22 & 24 & 67 \\
\hline \multirow{3}{*}{$\begin{array}{l}\text { Position of basal } \\
\text { concavity }(E q)\end{array}$} & range & $0.32-0.75$ & $0.18-0.59$ & $0.11-0.63$ \\
\hline & median & 0.578 & 0.415 & 0.427 \\
\hline & count & 22 & 24 & 67 \\
\hline
\end{tabular}


820 Table 6: Coefficients for the canonical discriminant analyses that best separate terrestrial fluvial and 821 debris flow gullies (A), terrestrial fluvial, terrestrial debris flow and martian gullies (B) and gullies

822 with different alcove types on Mars (C).

\begin{tabular}{|c|c|c|c|c|c|c|}
\hline & $\begin{array}{c}\text { Canonical } \\
\text { Coefficient } \\
\text { A1 }\end{array}$ & $\begin{array}{c}\text { Canonical } \\
\text { Coefficient } \\
\text { B1 }\end{array}$ & $\begin{array}{c}\text { Canonical } \\
\text { Coefficient } \\
\text { B2 }\end{array}$ & $\begin{array}{c}\text { Canonical } \\
\text { Coefficient } \\
\text { C1 }\end{array}$ & $\begin{array}{c}\text { Canonical } \\
\text { Coefficient } \\
\text { C2 }\end{array}$ & $\begin{array}{c}\text { Canonical } \\
\text { Coefficient } \\
\text { C3 }\end{array}$ \\
\hline Range in Slopes & 0.308 & 0.112 & -0.040 & -0.329 & 0.202 & 0.702 \\
\hline Average alcove slope & 0.786 & -1.276 & 0.177 & -0.182 & -0.223 & 1.027 \\
\hline $\begin{array}{l}\text { Average channel } \\
\text { slope }\end{array}$ & 0.385 & 0.051 & 0.111 & -1.035 & -0.274 & 0.571 \\
\hline $\begin{array}{l}\text { Average debris apron } \\
\text { slope }\end{array}$ & 0.413 & -0.308 & -0.128 & 0.026 & -1.180 & -0.193 \\
\hline Curvature $1\left(A_{\text {ero }}\right)$ & 0.430 & -0.347 & 0.213 & 0.362 & -0.153 & 0.059 \\
\hline Curvature $2(\mathrm{Cl})$ & -0.456 & 0.496 & -0.355 & -0.071 & -1.494 & -0.734 \\
\hline Curvaure 3 (७) & 0.109 & -0.892 & 0.027 & -0.265 & -1.248 & -0.406 \\
\hline $\begin{array}{l}\text { Position of basal } \\
\text { concavity }(E q)\end{array}$ & 0.842 & -0.028 & 0.607 & 0.027 & 0.296 & 0.178 \\
\hline Gradient & 0.861 & -1.980 & -0.431 & -0.193 & -1.375 & 1.476 \\
\hline
\end{tabular}

823 


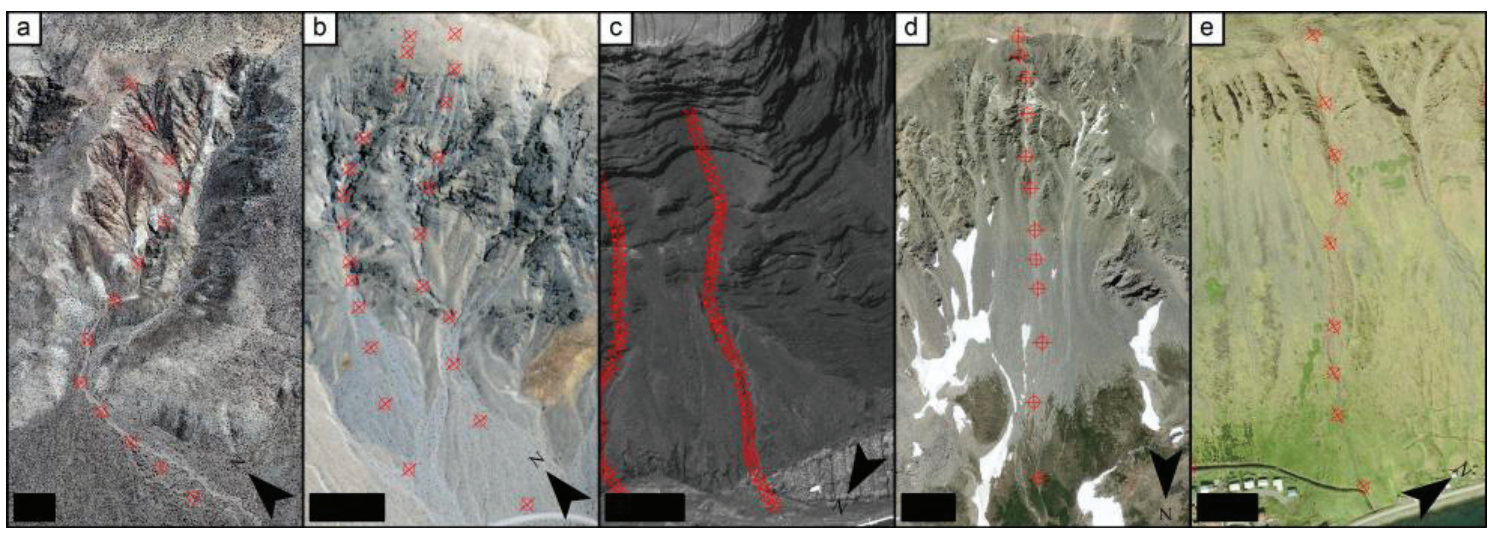

826 Figure 1: Overview images of the terrestrial gully-systems with locations of the profile points in red,

827 all scale bars are $100 \mathrm{~m}$. (a) Fluvial gully from the San Jacinto site, image from the USGS High

828 Resolution Orthoimagery collection, taken between $27^{\text {th }}$ May and $6^{\text {th }}$ June 2012. (b) Fluvial gully from

829 the Death Valley site, image from the USGS collection of he National Agriculture Imagery Program

830 (NAIP). (c) Fluvial gully from La Gomera study site, quickbird satellite image. (d) Debris flow gully

831 from the Colorado Front Range site, image from the USGS High Resolution Orthoimagery collection,

832 taken between $13^{\text {th }}$ March and $16^{\text {th }}$ November 2012. (e) Debris flow gully from the Westfjords site,

833 aerial image mosaic from the NERC ARSF 2007 survey IPY07-04. 


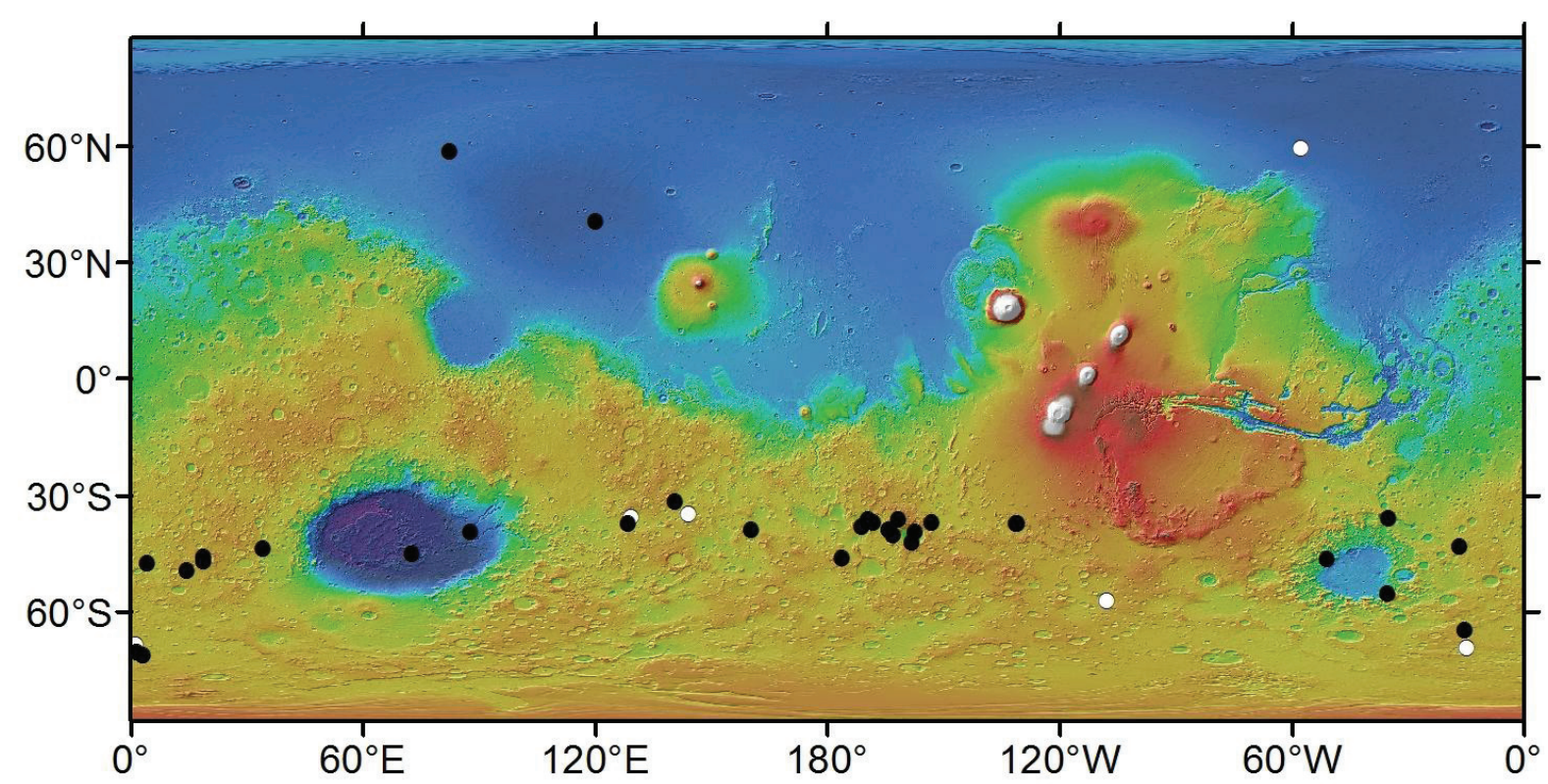

837 Figure 2: Locations of images (black dots) used for long-profile analysis on Mars and images excluded 838 from analysis (white dots) based on criteria laid out in Section 4. Background: Mars Orbiter Laser 839 Altimeter gridded data, credit MOLA Science Team/NASA/JPL. 


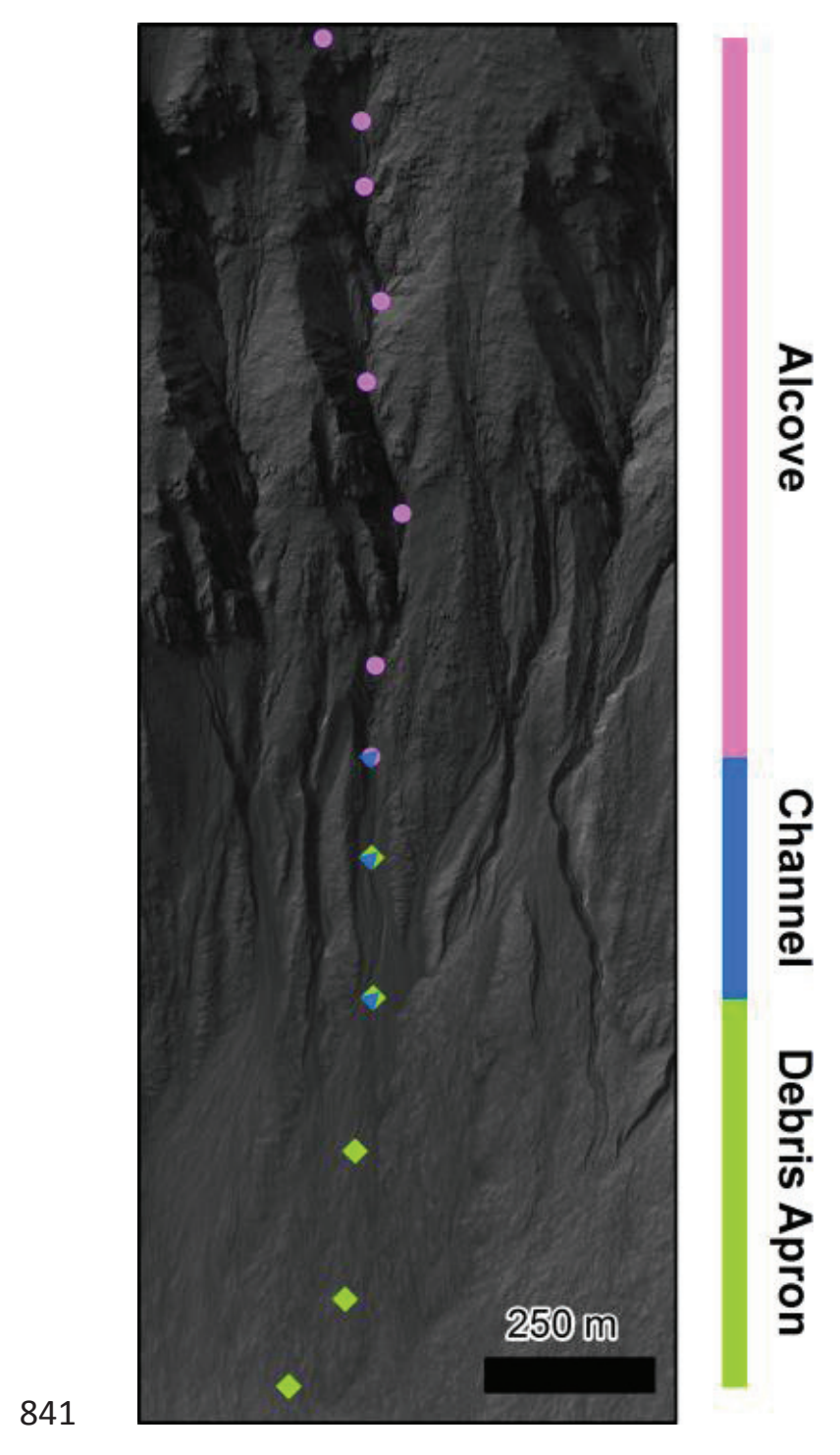

842 Figure 3: Illustration of a profile generated through the point-macthing method, HiRISE image 843 PSP_003583_1425. Visually matched points are shown by the markers and the different point 844 classifications (alcove, channel or debris apron) are shown by the different colours and shapes. Note 845 that any given point can have more than one classification. 


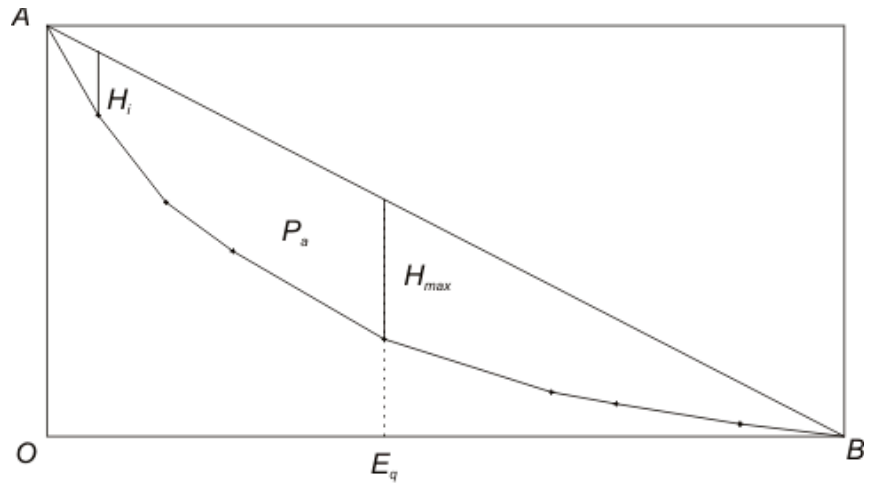

848 Figure 4: Annotated sketch of a typical long profile. $A$ is the source and $B$ is the distal end, with $P a$ 849 representing the area between the straight line $A B$ and the profile, $H_{i}$ is the elevation difference 850 between the straight line and the profile at point $i$ where $H_{\max }$ is the maximum value of $H_{i}$ and $E_{q}$ is 851 the proportion of the distance $O B$ to reach $H_{\max }$. 


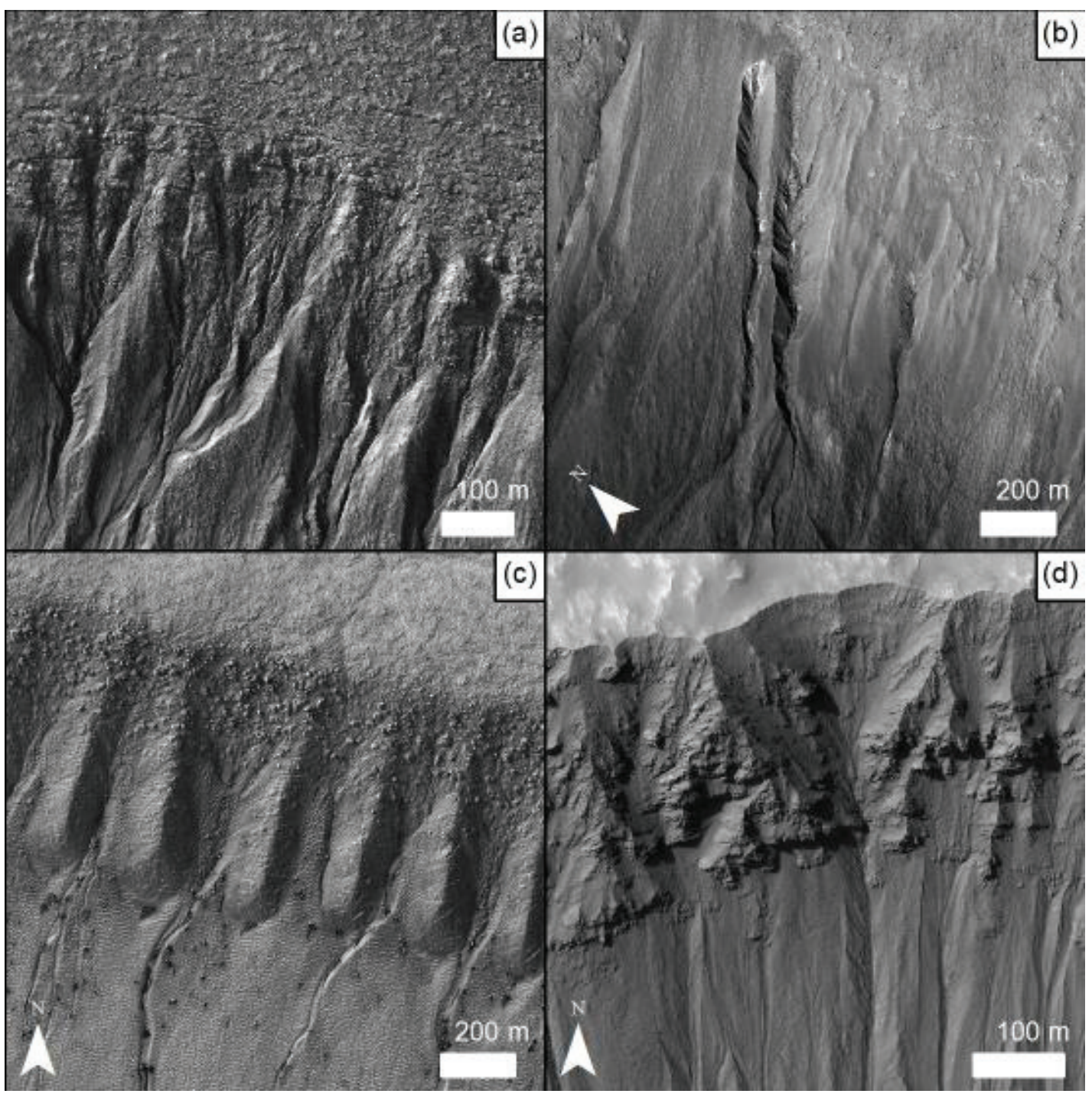

854 Figure 5 Examples of each alcove type used in this study. (a) "Open" type, where there is no

855 identifiable scarp or boundary delimiting the upper extent of the gully alcove. HiRISE image

856 PSP_001792_1425. (b) Cuspate alcove type, with a definite upper boundary mid-slopes, HiRISE

857 image PSP_002884_1395. (c) Bouldery type, with loose boulders and extending up to the crest of the

858 slope, only found in the polar pits, part of HiRISE image PSP_003498_1090. (d) Rockwall type, where

859 the alcove is into bedrock and extends up to the crest of the slope, part of HiRISE image PSP_005586_1425. Image credit: HiRISE team, UofA/NASA/JPL. 


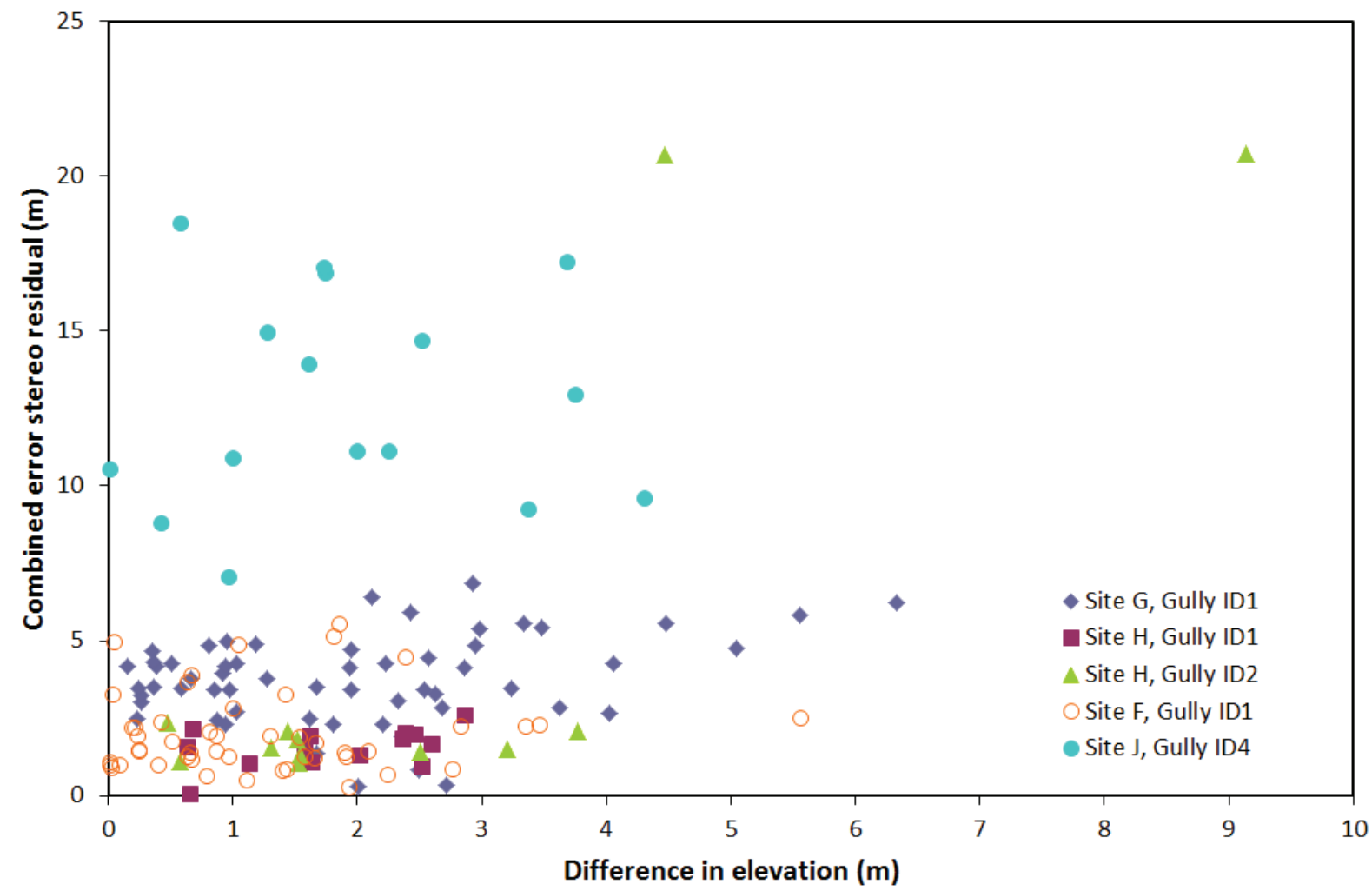

862 Figure 6: Comparison of the stereo error output by the Kreslavsky (2008) method and the absolute

863 difference in elevation between a digital elevation model and the elevations derived using the

864 Kreslavsky (2008) method. Sites names and gully IDs are the same as in Table 4 and the source DEMs are given in Table 3. 
A: Canonical scores

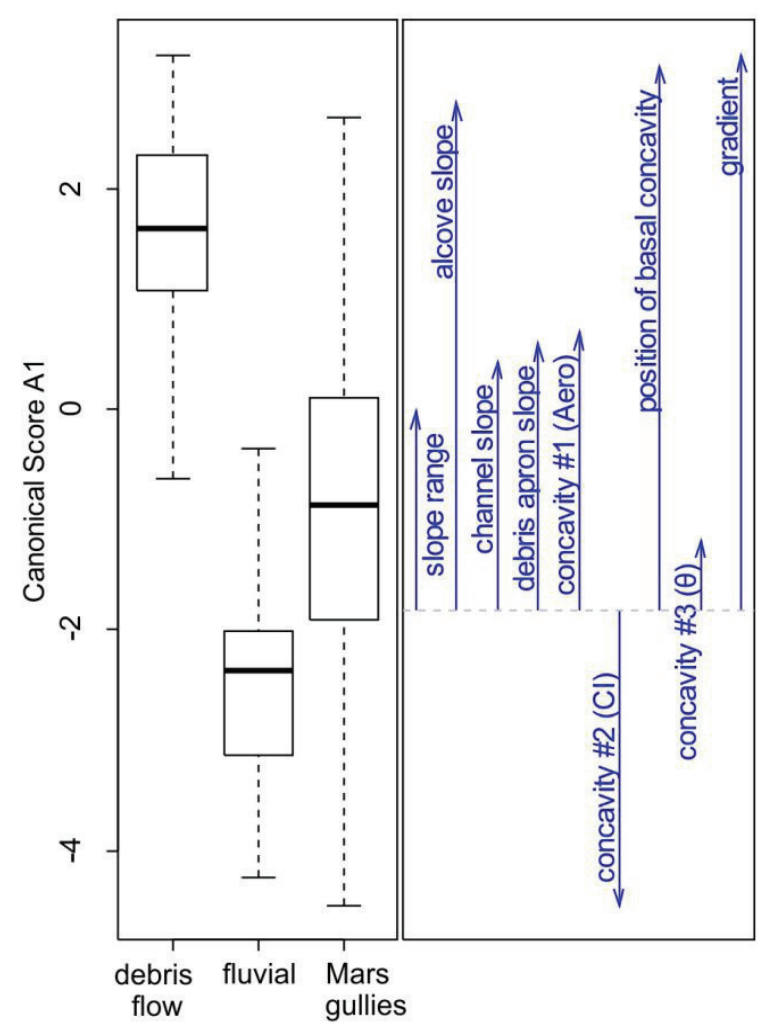

B: Canonical scores

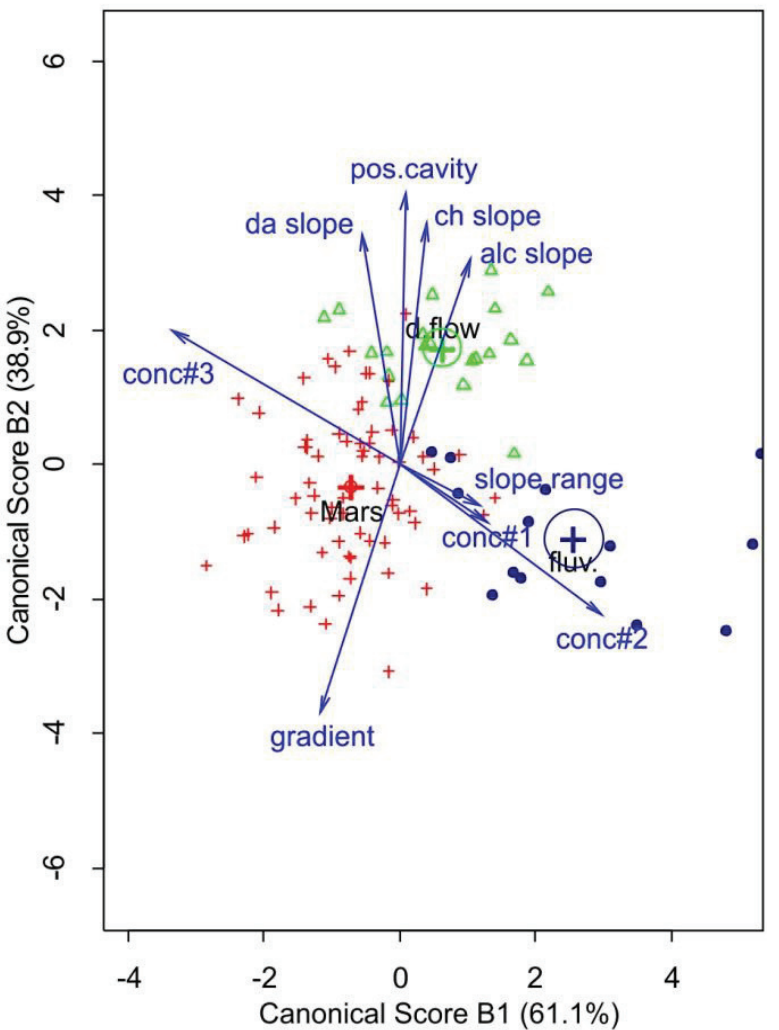

867 Figure 7: Canonical discriminant analyses of gully long profile parameters. Left: result of canonical

868 discriminant analysis to best separate fluvial and debris flow gullies on Earth, with a boxplot of the 869 distribution of function A1 for each gully type and the structure of the function A1 (Table 6), which

870 illustrates which parameters contribute and with what direction and magnitude. Right: result of

871 canonical discriminant analysis to best separate terrestrial fluvial, terrestrial debris flow and martian

872 gullies. Arrows illustrate the relative magnitude and direction of each parameter with respect the

873 canonical functions B1 and B2 (Table 6). Bold " + " are the group means, with corresponding circles

874 being the confidence on those means. In the boxplots, the thick bar across each box is the median value, the extent of the box delimits the interquartile range and the whiskers indicate the range. 


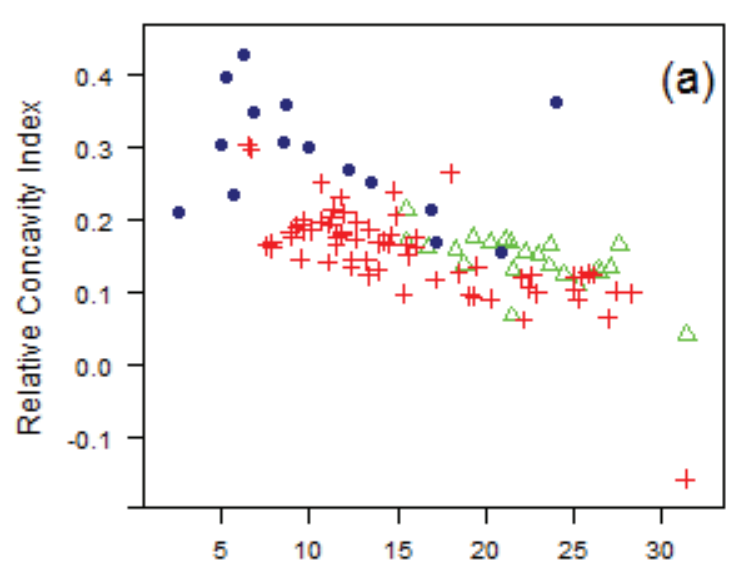

Average Debris Apron Slope / degrees

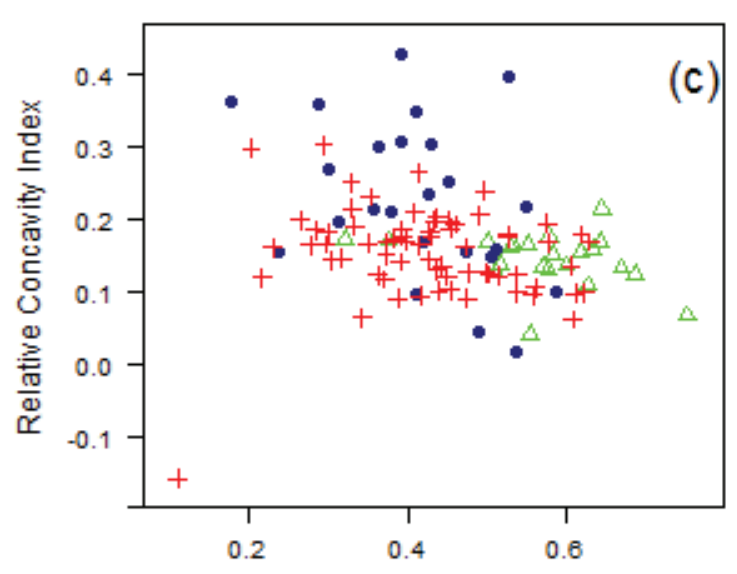

Relative position of maximal concavity

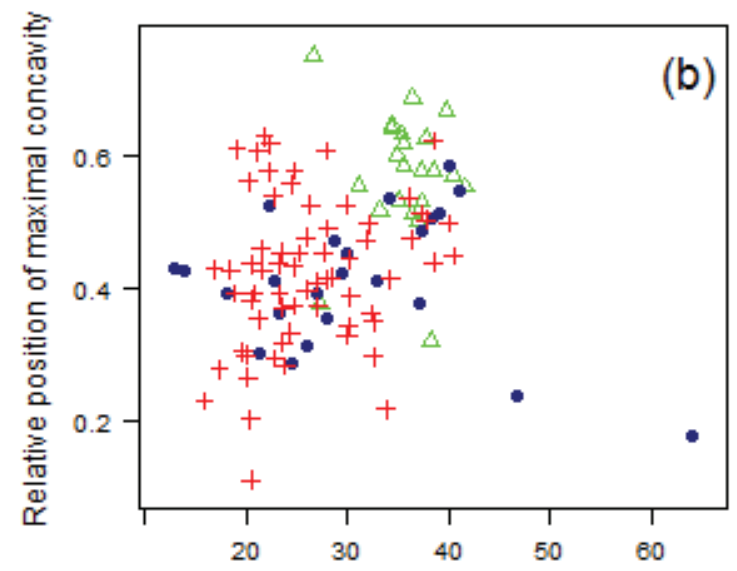

Average Alcove Slope / degrees

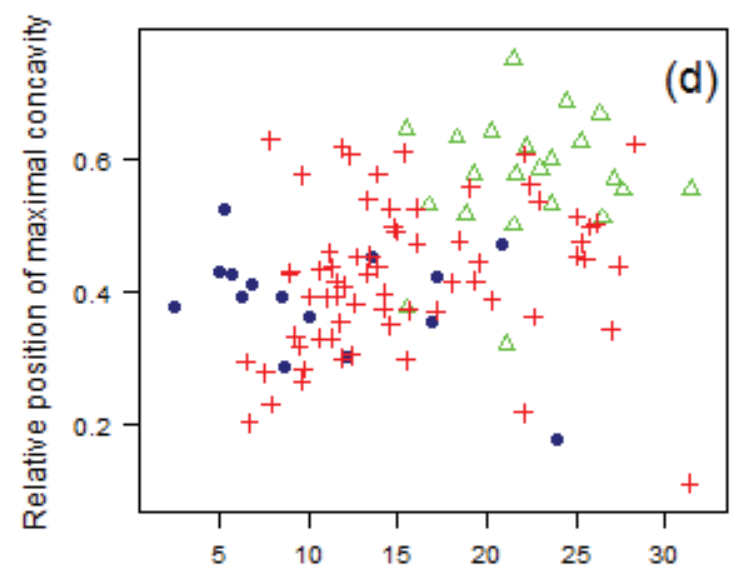

Average Debris Apron Slope / degrees

877 Figure 8: Scatterplots of profile parameters for terrestrial fluvial (filled circles), terrestrial debris flow

878 (open triangles) and martian gullies (+). (a) Relative concavity index $(\mathrm{Cl})$ against debris apron slope,

879 (b) relative position of basal concavity $(E q)$ against alcove slope, (c) Relative concavity index $(C /)$ against debris apron slope. 


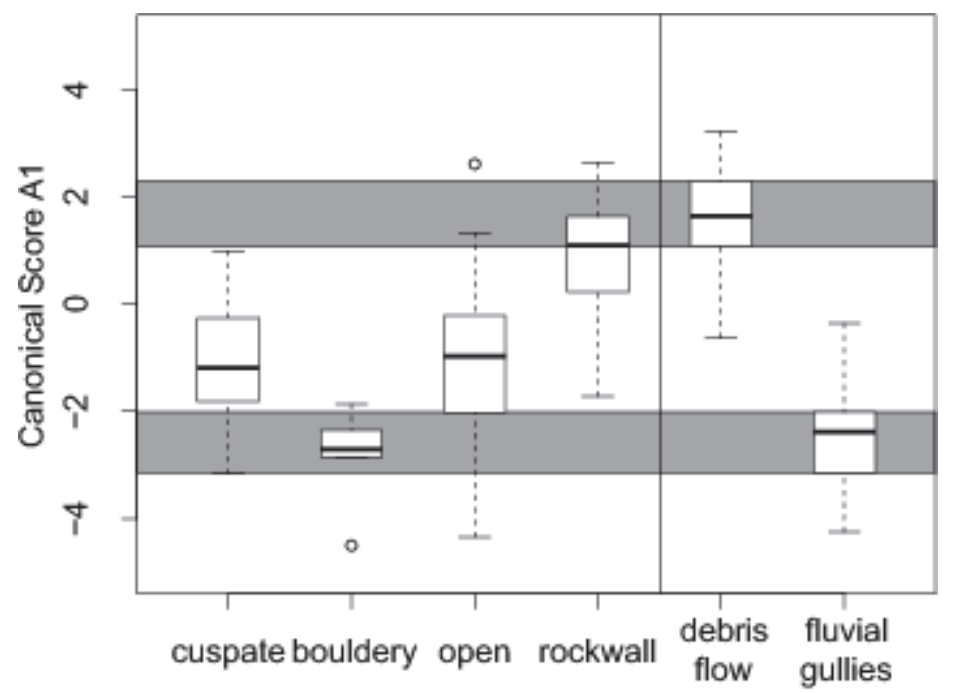

Figure 9: Boxplot showing the distribution of different martian gully alcove types with respect to canonical function A1 (Table 6), which best separates fluvial and debris flow gullies on Earth. In the boxplots, the thick bar across each box is the median value, the extent of the box delimits the interquartile range and the whiskers indicate the range, while the points are outliers - values which are further than 1.5 interquartile ranges from the quartiles. Grey horizontal rectangles project the data on the left.

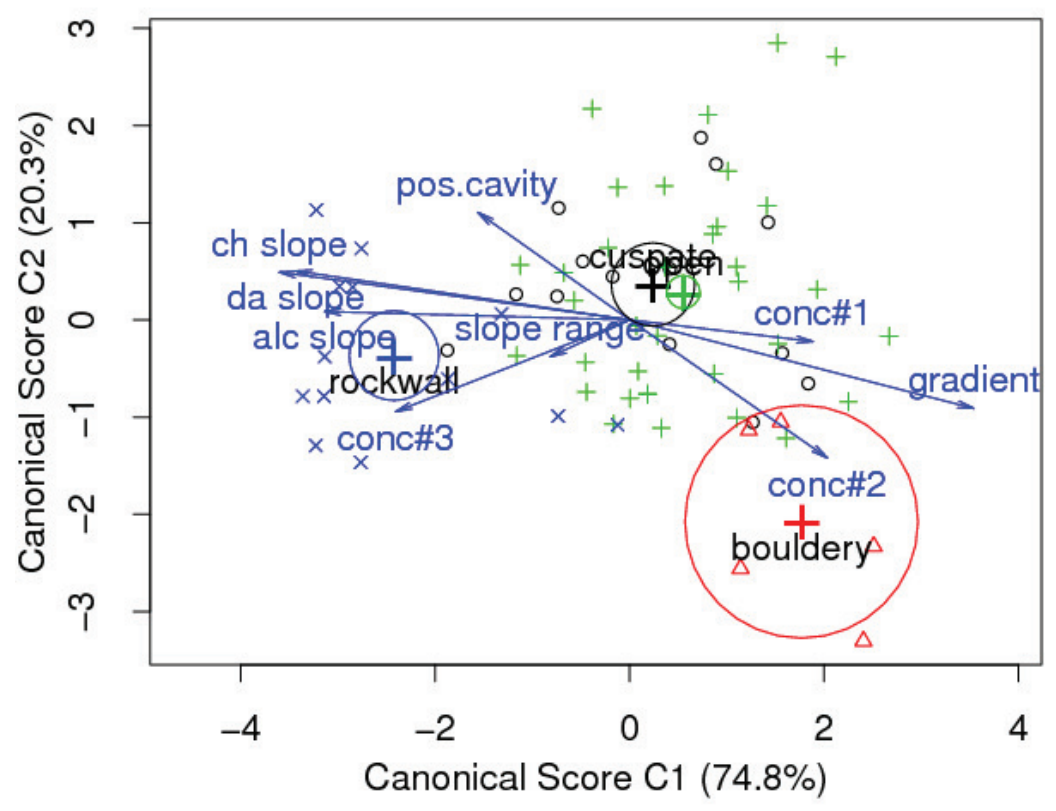


Figure 10: Canonical discriminant functions $C 1$ and $C 2$ (Table 6) separating different martian gully

892

893

894

895

896

897

898

899

900

901

902

903

904 alcove types based on long profile parameters. "o" are open alcove type, where there is no identifiable scarp or boundary delimiting the upper extent of the gully alcove. "+" are cuspate alcove type, with a definite upper boundary mid-slopes. " $\Delta$ " are bouldery alcove type, with loose boulders and extending up to the crest of the slope, only found in the polar pits. " $x$ " are rockwall alcove type, where the alcove is cut into bedrock and extends up to the crest of the slope. Bold " + " are the group means, with corresponding circles being the confidence on those means. Arrows illustrate the relative magnitude and direction of each parameter with respect the canonical functions $\mathrm{C} 1$ and $\mathrm{C} 2$.
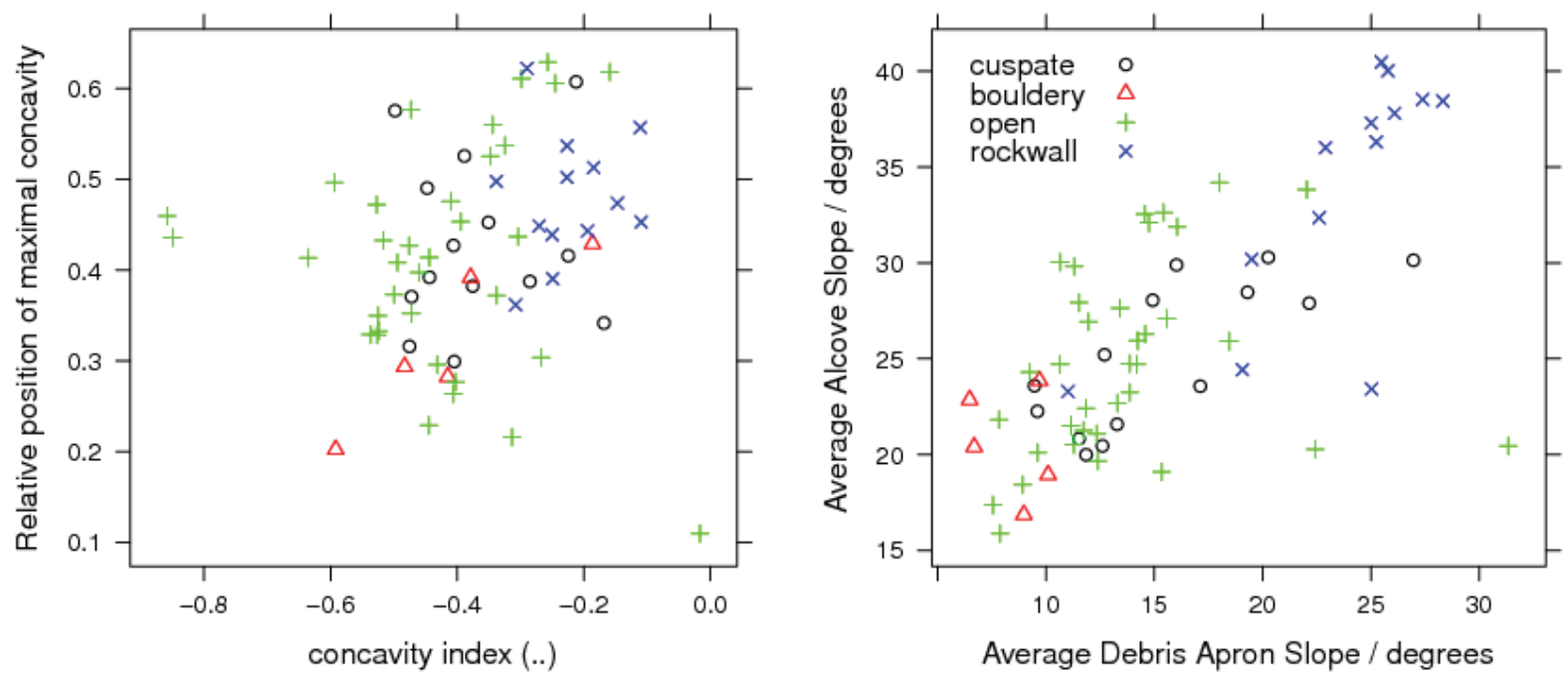

Figure 11: Scatterplots of long-profile parameters for different martian gully alcove types. Left: Relative position of maximal concavity $(E q)$ against concavity index $(\vartheta)$ and right: alcove slope against debris apron slope. 


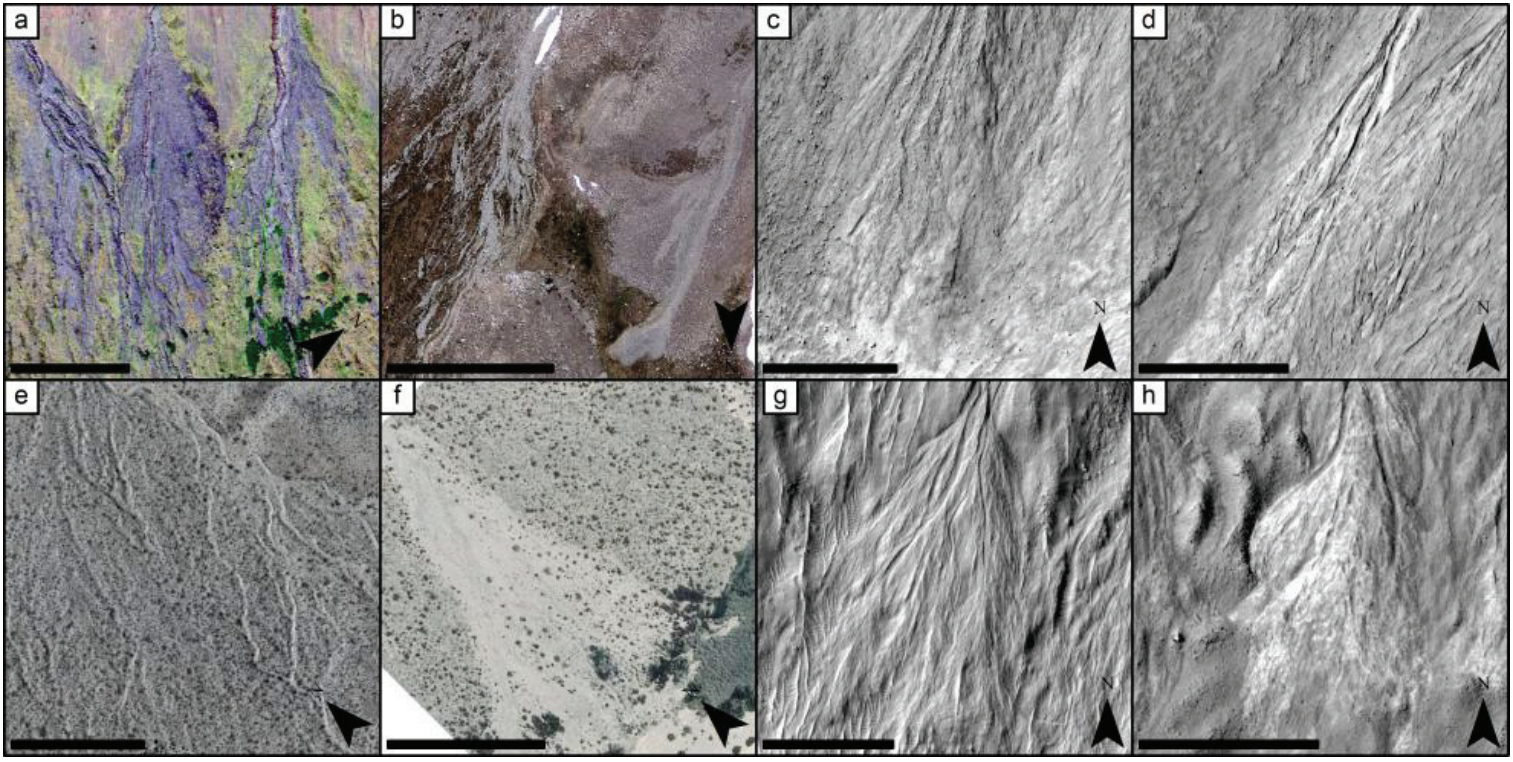

Figure 12: Comparison of depositional fans of gullies on Earth and Mars. Image credits for terrestrial

images are the same as in Fig. 1. All sace bars are $100 \mathrm{~m}$. (a) Debris flow depositional fans in the

Westfjords site. The fan on the left is a good example of cut-off and backfilled channel segments.

The channels visible in this image have levees, but the illumination is not favourable for their detection. The hummocky vegetated terrain between the channels is caused by overlapping debris fan-deposit comprised of multiple overlapping leveed flows and on the right is a single large lobate deposit. Levees are present on the flanks of the channels visible in this image, but lighting does not favour their visibility. (c) Gully-fan deposit on Mars in HiRISE image PSP_005586_1425. The fan is comprised of multiple overlapping lobate deposits which produce a hummocky fan surface. The main channel is flanked by small levees. (d) Gully-fan deposit on Mars in HiRISE image PSP_003674_1425. Simiarly to c) the fan is comprised of multiple overlapping lobate deposits which produce a hummocky fan surface. The fan has multiple channel segments, some of which are backfilled. (e) Alluvial fan dominated by fluvial processes at the San Jacinto site, which shows multiple channels across the fan surface and no lobate deposits (an overlay of the LiDAR shaded relief at 50\% transparency has been added to highlight these channels through the vegetation).

922 (f)Alluvial fan dominated by fluvial processes at the San Jacinto site, which shows low relief fresh 
923 deposits which infill topographic lows. (g) Gully-fan deposit on Mars in HiRISE image

924 PSP_001792_1425. The fan has low relief deposits that infill the lows between Transverse aeolian

925 ridges and has superposed channels which show some sinuosity. (f) Gully-fan deposit on Mars in

926 HiRISE image PSP_003215_1405. This fan has bright deposits which show no discernible relief.

927 
929 In an ideal world, measurements of local elevation differences from stereo pairs work in the

930 following way. Here we assume that the scene is much smaller than the distance to the camera and

931 the planetary radius, and that the image is map-projected without distortion. Rigorous

932 photogrammetric solutions deal with finite distance to the camera and non-map-projected images.

933 With the latter assumption, pixel coordinates in the images $X, Y$ are related to local Cartesian coordinates $x, y$ at the surface through simple scaling:

$$
x=S X
$$

$$
y=S Y
$$

where $S$ is the scale in metres per pixel.

Say we have two images $A$ and $B$ taken with different positions of the camera relative to the scene. Direction from the scene to the camera is described by two angles: camera zenith angle $\vartheta$ (i.e., emergence angle), and camera azimuth $\varphi$. The azimuth is measured from $x$-axis toward $y$-axis. Thus, the complete description of the observation geometry for the stereo pair is given by four angles $\vartheta_{A}, \varphi_{A}, \vartheta_{B}, \varphi_{B}$.

We can identify the same two points 1 and 2 in images $A$ and $B$ and measure their Cartesian coordinates in the images: $\left(x_{A 1}, y_{A 1}\right),\left(x_{B 1}, y_{B 1}\right),\left(x_{A 2}, y_{A 2}\right),\left(x_{B 2}, y_{B 2}\right)$. If the surface is horizontal, the images $A$ and $B$ are identical, and $x_{A 2}-x_{A 1}=x_{B 2}-x_{B 1}, y_{A 2}-y_{A 1}=y_{B 2}-y_{B 1}$. If there is some elevation difference $h$ between points 2 and 1 , there is non-zero parallax vector $\boldsymbol{l}$ defined as:

$$
\boldsymbol{l} \equiv\left(\begin{array}{l}
l_{x} \\
l_{y}
\end{array}\right) \equiv\left(\begin{array}{c}
\left(x_{B 2}-x_{B 1}\right)-\left(x_{A 2}-x_{A 1}\right) \\
\left(y_{B 2}-y_{B 1}\right)-\left(y_{A 2}-y_{A 1}\right)
\end{array}\right)
$$
the parallax vector from the elevation difference and observation geometry: 


$$
\boldsymbol{l}=h\left(\begin{array}{c}
\tan \theta_{A} \cos \varphi_{A}-\tan \theta_{B} \cos \varphi_{B} \\
\tan \theta_{A} \sin \varphi_{A}-\tan \theta_{B} \sin \varphi_{B}
\end{array}\right) \equiv h \boldsymbol{p}
$$
estimate of the elevation difference $h$. The best solution of this over defined problem is given by:

$$
h=\frac{\boldsymbol{l} \cdot \boldsymbol{p}}{\boldsymbol{p}^{2}}=\frac{l_{x}\left(\tan \theta_{A} \cos \varphi_{A}-\tan \theta_{B} \cos \varphi_{B}\right)+l_{y}\left(\tan \theta_{A} \sin \varphi_{A}-\tan \theta_{B} \sin \varphi_{B}\right)}{\tan ^{2} \theta_{A}+\tan ^{2} \theta_{B}-2 \tan \theta_{A} \tan \theta_{B} \cos \left(\varphi_{B}-\varphi_{A}\right)}
$$

Since the problem is over defined, we have also the residual:

$$
\left|l-\frac{l \cdot p}{p^{2}} p\right|
$$

which would be zero, if the points were identified absolutely correctly and geometry were calculated absolutely correctly. It is convenient to express the residual in "vertical units", so that it characterizes an equivalent error in determination of $h$ :

$$
r \equiv \frac{1}{p}\left|\boldsymbol{l}-\frac{\boldsymbol{l} \cdot \boldsymbol{p}}{\boldsymbol{p}^{2}} \boldsymbol{p}\right|=\frac{\left|l_{y}\left(\tan \theta_{A} \cos \varphi_{A}-\tan \theta_{B} \cos \varphi_{B}\right)-l_{x}\left(\tan \theta_{A} \sin \varphi_{A}-\tan \theta_{B} \sin \varphi_{B}\right)\right|}{\tan ^{2} \theta_{A}+\tan ^{2} \theta_{B}-2 \tan \theta_{A} \tan \theta_{B} \cos \left(\varphi_{B}-\varphi_{A}\right)}
$$

961

962
In summary, we measure $\left(x_{A 1}, y_{A 1}\right),\left(x_{B 1}, y_{B 1}\right),\left(x_{A 2}, y_{A 2}\right),\left(x_{B 2}, y_{B 2}\right)$, then use Equations $A 2$ and $A 4$ to obtain the elevation difference $h$ and Equation A5 to obtain the residual and assess the accuracy.

This approach can be generalized for the case when we have not two, but $N$ points, and we want to have mutually consistent elevation differences between them. We measure $\left(x_{A j}, y_{A j}\right),\left(x_{B j}\right.$, $\left.y_{B j}\right), j=1, \ldots, N$. Then we calculate coordinates $\left(x_{A 0}, y_{A 0}\right),\left(x_{B 0}, y_{B 0}\right)$ of a "base" point:

$$
x_{A 0}=\frac{1}{N} \sum_{j=1}^{N} x_{A j} ; y_{A 0}=\frac{1}{N} \sum_{j=1}^{N} y_{A j} ; x_{B 0}=\frac{1}{N} \sum_{j=1}^{N} x_{B j} ; y_{B 0}=\frac{1}{N} \sum_{j=1}^{N} y_{B j}
$$

and $N$ parallax vectors with respect to the base point:

$$
l_{j}=\left(\begin{array}{l}
\left(x_{B j}-x_{B 0}\right)-\left(x_{A j}-x_{A 0}\right) \\
\left(y_{B j}-y_{B 0}\right)-\left(y_{A j}-y_{A 0}\right)
\end{array}\right), j=1, \ldots, N .
$$


obtain a scaled residual. All elevations $h_{j}$ are measured with respect to the same arbitrary datum

971 (elevation of the "base" point).

972

In the real world, HiRISE map-projected images (so-called RDR, or Reduced Data Records) are

formally not suitable for such parallax calculations because (1) the observation geometry varies

974 across the image, and (2) the images are orthorectified, that is they are map-projected assuming some smoothed surface topography.

There are two ways to overcome this difficulty. The more accurate way is proposed by the HiRISE team: start with raw non-projected non-mosaiced data (EDR, or Experimental Data Records), run them through a sequence of USGS ISIS3 programs (Anderson et al., 2004; Gaddis et al., 1997) to obtain a special image product, that can be used for parallax calculations in more or less similar way to that described above (some modification will be needed, as the result is not actually mapprojected).

This method uses a different approach, which is less accurate, but much quicker. It uses the RDR data set and ignores difficulty (1) above. The ignored variations of observation geometry can lead to $1.5^{\circ}$ varying bias in measured slopes. However, the method accurately accounts for difficulty (2) by compensating distortion introduced by the orthorectification procedure. 
989 Figure S1: Hillshade relief maps for each of the sites studied on Earth, with the long profiles included 990 in this study marked by red points. Scale bars are all $1 \mathrm{~km}$ and north is up. The LiDAR elevation 991 datasets are listed in Table 1. The background elevation data used is SRTM, except for the 992 Westfjords site where it is the EUDEM. (a) San Jacinto, (b) Death Valley, (c) La Gomera, (d) Front 993 Range and (e) Westfjords.

Figure S2: HiRISE images for each site studied on Mars with long profile points marked. Scale bars

996 are all $1 \mathrm{~km}$ and north is up. Each panel is labelled with the numerals of the first and second HiRISE

997 image used (listed in Table 2). Profiles marked with crosses were excluded from further analysis as 998 they did not satisfy the stereo error criterion. The image used in each panel is the HiRISE image with 999 the lowest numeral value from each pair. 